NBER WORKING PAPER SERIES

SHORT INTEREST AND STOCK RETURNS

\author{
Paul Asquith \\ Parag A. Pathak \\ Jay R. Ritter
}

Working Paper 10434

http://www.nber.org/papers/w10434

\author{
NATIONAL BUREAU OF ECONOMIC RESEARCH \\ 1050 Massachusetts Avenue \\ Cambridge, MA 02138 \\ April 2004
}

We would like to thank the NYSE, Amex, and Nasdaq for supplying us with short interest data, and to Lisa Meulbroek for helpful contributions. This paper substantially revises and extends the 1995 working paper "An Empirical Investigation of Short Interest" by Paul Asquith and Lisa Meulbroek. Comments from Burt Porter and workshop participants at Barclays Global Investors and the University of North Carolina are appreciated. In addition, we thank Vivek Bohra, Jeff Braun, Stefan Budac, Jason Hotra, Carl Huttenlocher, Kevin Kadakia, and Matthew Zames for their research assistance. The views expressed herein are those of the author(s) and not necessarily those of the National Bureau of Economic Research.

(C2004 by Paul Asquith, Parag A. Pathak, and Jay R. Ritter. All rights reserved. Short sections of text, not to exceed two paragraphs, may be quoted without explicit permission provided that full credit, including (C) notice, is given to the source. 
Short Interest and Stock Returns

Paul Asquith, Parag A. Pathak, and Jay R. Ritter

NBER Working Paper No. 10434

April 2004

JEL No. G12, G14

\title{
ABSTRACT
}

Using a longer time period and both NYSE-Amex and Nasdaq stocks, this paper examines short interest and stock returns in more detail than any previous study and finds that many documented patterns are not robust. While equally weighted high short interest portfolios generally underperform, value weighted portfolios do not. In addition, there is a negative correlation between market returns and short interest over our whole period. Finally, inferences from short time periods, such as 1988-1994 when the underperformance of high short interest stocks was exceptional or 1995-2002, when high short interest Nasdaq stocks did not underperform, are misleading.

\author{
Paul Asquith \\ Sloan School of Management \\ MIT, Room E52-325 \\ 50 Memorial Drive \\ Cambridge, MA 02142 \\ and NBER \\ pasquith@mit.edu \\ Parag A. Pathak \\ Department of Economics \\ Harvard University \\ ppathak@fas.harvard.edu \\ Jay R. Ritter \\ Warrington College of Business Administration \\ University of Florida \\ jay.ritter@cba.ufl.edu
}




\section{Short Interest and Stock Returns}

\section{Introduction}

It is now widely accepted that stocks with high short interest ratios underperform the market. This is a very recent bit of conventional wisdom, based largely on the evidence in Asquith and Meulbroek's (1995) unpublished working paper for New York Stock Exchange (NYSE) and American Stock Exchange (Amex) stocks, and Desai, Ramesh, Thiagarajan, and Balachandran's (2002) article for Nasdaq stocks. Both Asquith and Meulbroek and Desai et al report negative and significant abnormal returns for firms with short interest ratios of $2.5 \%$ or more, where the short interest ratio is defined as the ratio of short interest to shares outstanding. Both papers also report large secular increases in short interest ratios, and skewed cross-sectional distributions, with most stocks having short interest ratios of less than $0.5 \%$, and very few firms having a ratio exceeding $10 \%$. Prior to these papers, the conventional wisdom was that large short positions presaged positive future returns, caused by the flow demand from short sellers covering their positions.

The rationale for why high short interest should presage negative abnormal returns relies upon the fact that short selling stocks is costly or constrained relative to taking long positions. There are many reasons for this, primarily regulatory constraints. If short selling is costly, the "votes" of optimistic investors carry a greater weight than those of pessimistic investors in stock valuation. Two predictions flow from these observations. First, firms with a high dispersion of opinion will be overvalued, and thus have low subsequent returns, as first discussed by Miller (1977). Second, since short sellers will concentrate their positions in the firms that are most overvalued, firms with high short interest ratios will have low subsequent returns, as modeled by Diamond and Verrecchia (1987).

This paper shows that the new conventional wisdom regarding short interest ratios and return predictability, as well as continual increases in short interest ratios over time, is premature and incomplete. Using a longer time period for both NYSE-Amex and Nasdaq stocks and examining short interest and stock returns in more detail than any previous study, we find that the patterns are more ambiguous than the recent literature suggests. While the result that high

\footnotetext{
${ }^{1}$ This idea is named the "Cushion Theory" in Barron's Dictionary of Finance and Investment Terms, $5^{\text {th }}$ edition, 1998.
} 
short interest stocks underperform is generally true for equally weighted portfolios, it does not hold for value weighted portfolios. Specifically, for the period from 1976 to 2002, equally weighted (EW) portfolios of NYSE-Amex and (beginning in July 1988) Nasdaq firms with high short interest reliably underperform. These same portfolios over the same calendar time period, however, do not reliably underperform on a value weighted (VW) basis. For example, firms in the $99^{\text {th }}$ percentile of short interest ratios have monthly abnormal returns of -53 basis points $(\mathrm{t}=$ 2.44) on an EW basis, but only -5 basis points $(t=-0.17)$ on a VW basis. This difference is not because highly shorted stocks are all micro-caps, however. While highly shorted stocks have a larger median equity value than the median of non-highly shorted stocks, they are disproportionately small stocks, with both micro-cap stocks and large-cap stocks underrepresented. This is true for the entire sample and for the subsamples of NYSE-Amex and Nasdaq firms.

In addition to the differences between EW and VW portfolios, over the period 19882002, when data for all markets are available, there are differences between NYSE-Amex and Nasdaq firms. The abnormal returns on NYSE-Amex stocks with high short interest are more negative and more consistent across portfolios than for Nasdaq stocks.

Consistent with other studies, we find that the higher the short interest ratio, the lower is the subsequent performance. That is, firms with short interest ratios of $10 \%$ or more underperform those of $5 \%$ or $2.5 \%$. Likewise, firms that are in the $99^{\text {th }}$ percentile of short interest underperform firms in the $95^{\text {th }}$ percentile. These are not fair comparisons, however, since these portfolios are not distinct. The $2.5 \%$ portfolio includes stocks in the $5 \%$ and $10 \%$ portfolio. Likewise the $95^{\text {th }}$ percentile portfolio includes stocks in the $99^{\text {th }}$ percentile portfolio. This suggests that the magnitude and significance of abnormal returns for the less restrictive portfolios are driven by stocks with the highest short interest.

We examine this issue using truncated portfolios, i.e. $2.5-4.9 \%, 5-9.9 \%$, and $95-98.9^{\text {th }}$ percentiles, and find that this is in fact the case. For the sample of NYSE-Amex-Nasdaq firms over the period 1988-2002, the truncated portfolio returns are not as negative or significant as are the corresponding untruncated portfolio returns. In general, the portfolios with reliably negative abnormal returns are EW portfolios with high short interest ratios. These stocks comprise a small percentage of all firms and market capitalization. In a typical year, there are 5,500 domestic operating companies trading on the NYSE, Amex, and Nasdaq National Market System. Only 55 
of them are in the $99^{\text {th }}$ percentile, which is the portfolio with the worst performance. For the other 5,445 firms, short interest ratios have only a modest ability to predict abnormal returns.

Moreover, our results are not as significantly negative as those reported by Asquith and Meulbroek (1995) and Desai et al (2002). Differences with Desai et al's results are due to the fact that during the period they analyze, July 1988-1994, stocks with high short interest do exceptionally poorly, on both an EW and VW basis. In fact, returns to highly shorted stocks for all markets in this subperiod are the most negative of any subperiod that we examine. In other subperiods, in particular the 1995-2002 period, not covered by Asquith and Meulbroek or Desai et al, EW Nasdaq portfolios and all VW portfolios of high short interest stocks do not reliably underperform the market.

Our differences with the Asquith and Meulbroek results are not only due to the time period they examine. The differences are also attributable to different methodologies. First, they do not measure returns using a four-factor model as we and Desai et al do. Second, in the most often-cited early versions of the paper (later corrected), they calculate the abnormal return on stock $i$ as $\ln \left(1+r_{i t}\right)-\ln \left(1+r_{m t}\right)$, where $r_{i t}$ and $r_{m t}$ are the firm return and market return in month $t$. This empirical procedure produces biased abnormal returns, since expected log returns depend upon both the mean and the variance of the simple returns. Since individual stock returns have a higher variance than the market return, the expected market-adjusted log return is negative in random samples, with the bias approximately equal to $1 / 2$ the average unique variance. If the average variance of idiosyncratic returns is $(0.3)^{2}$ per year (30 percent squared), the bias is almost 40 basis points per month.

Taken together, this implies that the new conventional wisdom about the poor performance of stocks with high short interest is based on Nasdaq stocks for an atypical six-andone-half year sample period, and on a biased methodology that does not consider the FamaFrench risk factors for NYSE-Amex stocks. It is also based only on EW portfolios.

Our results also differ from the existing literature on other dimensions. Asquith and Meulbroek and Desai et al report that there has been a continual increase in short interest ratios over time. Lamont and Stein (2004) report that short interest ratios declined during part of the period 1995-2002 and that there is a large negative correlation between stock returns and short interest for the Nasdaq market. All three studies examine too short a time period to draw general conclusions. We find that short interest did not continue to rise steadily in the period subsequent 
to that examined in Asquith and Meulbroek and Desai et al. Short interest as a percentage of market value declined for Nasdaq in 1999 and 2000. Short interest ratios on Nasdaq subsequently rose after Nasdaq prices peaked, reaching their highest level in 2002. NYSE-Amex short interest ratios fell in 1998 and also reached a new peak in 2002. Examining market returns and short interest for our longer period and on all markets, we find a negative correlation that is much smaller than that reported by Lamont and Stein.

We also find that the negative performance of stocks with high short interest is less persistent than Desai et al report. In most subperiods, there is a fairly rapid decay of negative abnormal performance towards zero, once short interest ratios fall. Specifically, portfolios that remove firms with high short interest as soon as the short interest ratio drops below a fixed threshold have more negative abnormal returns than those that keep a firm in the portfolio for some additional inclusion period, e.g. 12 months. Thus, to implement a strategy that is restricted to firms with a high short interest ratio, portfolio turnover must be extensive, and this would result in an implementation shortfall relative to returns that are estimated ignoring transaction costs.

Individual stocks have high short interest for a variety of reasons. Some stocks have high short interest because some investors feel they are overvalued (valuation shorts). Other stocks have high short interest because some investors feel that a convertible bond issued by the company is undervalued (arbitrage shorts). When we categorize stocks in our high short interest portfolios on the basis of whether they may be subject to convertible bond arbitrage, we find that the arbitrage short sellers do not profit as much as value-based short sellers.

The remainder of this paper is organized as follows. Section II reviews related literature, while Section III describes the data and the research design. Section IV presents the main empirical results, while Section V considers arbitrage versus valuation-based short selling. Section VI outlines some implications of our results and concludes. The Appendix contains institutional details on the procedures of short selling.

\section{Related Literature}

Short sales restrictions were originally passed to prevent downward pressure on stock prices (Jones and Lamont (2002)) and short sellers remain reviled today by firm managers (Lamont (2002)). Rubinstein (2004) surveys the theoretical models on short sales and their effect 
on stock returns. This literature relies on both institutional restrictions on short sales and heterogeneous beliefs among investors. The modern empirical literature showing that short sales affect subsequent stock returns begins with Asquith and Meulbroek (1995) and Desai et al (2002). Prior to these papers, empirical research did not identify a strong or consistent relationship between short interest and subsequent returns (see Figlewski (1981), Brent, Morse and Stice (1990), Figlewski and Webb (1993), and Woolridge and Dickinson (1994)). One reason for this failure is that some of these previous studies did not select their sample firms based upon the level of short interest. The relation between short interest and returns is difficult to detect using a random sample since a large percentage of firms have little or no short interest in any given month. In their study of the announcement effects of short interest, Senchek and Starks (1992) do look at levels of short interest, but their sample size is limited.

Contemporaneous research on short interest and stock returns includes Gopalan (2003) and Boehme, Danielson, and Sorescu (2002). Gopalan examines the relation between short interest ratios and subsequent returns for a sample of NYSE and Nasdaq stocks from 1992-2000. He finds that stocks that are likely to be short sale constrained earn lower one month ahead returns compared to unconstrained stocks. Boehme et al examine the relation between short interest and abnormal returns in the period January 1988 through July 1999 for NYSE-listed stocks and January 1993 through July 1999 for Nasdaq-listed stocks. They sort stocks into portfolios based on market capitalization, short interest ratios, and the standard deviation of residuals from a market model regression for the prior one hundred trading days. They report that the underperformance of stocks with a high short interest ratio is concentrated among smaller stocks with a higher residual standard deviation.

Other work focuses on why stocks are shorted and explores the costs of short selling. For example, Dechow, Hutton, Meulbroek and Sloan (2001) document that short sellers position themselves in firms with low ratios of fundamentals (such as earnings and book values) to market values and cover their positions as ratios mean-revert. Geczy, Musto, and Reed (2002), D'Avolio (2002), and Jones and Lamont (2002) examine smaller proprietary databases of stocks that are "on special," where short sellers must pay a premium to borrow shares. They find that these stocks are more likely to have high short interest ratios. Ofek, Richardson, and Whitelaw (2003) find that stocks which are difficult to short are more likely to violate put-call parity. While these last four papers have detailed data on rebate rates and study the costs of short selling 
in depth, none of them examine short selling and stock returns for NYSE-Amex and Nasdaq stocks for as long a time period as our paper does.

\section{Data and Research Design}

\section{A. Sample Construction}

We use a sample of NYSE and Amex firms from 1976-2002 and Nasdaq firms from July 1988-December 2002. The NYSE, Amex, and Nasdaq report the level of short interest in individual stocks monthly. This information is typically collected from member firms on the fifteenth calendar day of every month (if it is a business day) and released (after the close of trading) to news services at least four (and usually more) business days later. Nasdaq has traditionally released the information a few days later than the NYSE and Amex. This information is from the settlement date and represents short positions established in transactions that occurred three or five business days prior (the settlement period changed from 5 to 3 days in June 1995). The short interest positions for some, but not all, listed firms are then reported in the Wall Street Journal, Barron's, and the New York Times. In recent years, they are also listed on Bloomberg. Reporting dates vary from month to month since exchanges have no required release date. The data is sometimes published as early as the $19^{\text {th }}$, sometimes as late as the $1^{\text {st }}$ of the next month. The markets and the financial press report both the current and past month short interest together. The short interest data are frequently revised the following month. These revisions occur primarily because a member firm is tardy in reporting, and its short interest is not included in the initial amount reported. Most revisions are quite small and where the revised numbers are provided, we use the revised numbers.

The short interest data in this paper are from five sources. The first two sources are the NYSE and Amex, which began selling their monthly short interest data to the public in January 1991. The third source is Nasdaq, which began supplying data in electronic form on a monthly basis in June 1988, although February and July 1990 are missing. Nasdaq monthly short interest data for months starting in January 1994 is available on the Nasdaq website. The last two sources

\footnotetext{
${ }^{2}$ One problem with using newspapers as a source of data is that they limit their coverage of short interest positions to firms with the largest number of shares sold short or firms with large changes in short interest. The cut-off criteria also changes over time. For example, the August 2000 Wall Street Journal reports short sales for NYSE and Amex firms with positions greater than 850,000 shares or whose short positions changed by more than 525,000 shares since the last month. The Nasdaq numbers for August 2000 are 575,000 and 350,000 respectively. In August 1995, the short sale cut-offs for NYSE-Amex firms are 300,000 and 50,000. In general, the reporting requirements have increased, reflecting stock splits and the general increase in short sales.
} 
are owned by Standard and Poor's and are roughly equivalent. Interactive Data Corporation (IDS), a subsidiary of Standard and Poor's, publishes a Quarterly History Tape, which provides 12 months of short interest data for each firm. This is the primary source for our NYSE and Amex data prior to 1991. Standard and Poor's Daily Stock Price Record, published quarterly, lists 12 months of short interest data for each firm on the NYSE and Amex for the entire period. This source was used repeatedly to check revisions in monthly short interest. All the sources we use are more comprehensive in their coverage of short interest positions than the financial press. For example, in December of 1990, Barron's reports short interest for 986 NYSE-Amex firms whereas the Standard and Poor's sources report short interest for 1,335 firms.

The difference between the Standard and Poor's data and the exchange data is that the exchanges report a value for short interest for every firm, even if the firm has no or low short interest. For instance, in December 1990, the Standard and Poor's sources report short interest data for 1,335 NYSE and Amex firms. In January 1991, the NYSE and Amex provide December 1990 data for 1,854 firms, of which 1,766 firms have non-zero entries. The Standard and Poor's sources therefore omit 431 firms that have a small amount of short interest. The data provided by the exchanges reveals that the average short interest for these 431 firms in January 1991 is 3,825 shares, equivalent to $0.07 \%$ of shares outstanding. For stocks with no reported short interest in a given month, we assume the short interest is zero for that month. This paper uses the Standard and Poor's sources for the 1976-1990 data for the NYSE and Amex. Post-1990 come directly from the exchanges. For all months for which we have Nasdaq data, Nasdaq is the source.

Numerous cross-checks were performed to ensure data accuracy. Since the quarterly Standard and Poor's sources each contain 12 months of data and the monthly exchange data each contains two months, we compared overlapping months to search for data problems. We also identified outliers based on deviations from moving averages and compared the observations to data published in Barron's and listed in Bloomberg. Since Barron's lists two months of data in each of its reports, we compared each data point to two separate issues of Barron's. In total, we manually checked approximately 50,000 data points.

\footnotetext{
${ }^{3}$ We do not believe that we have completely corrected this database; indeed it is our belief that it would be impossible to do so. We do believe that we have eliminated the obvious errors in the data. Often the errors appear straightforward, e.g. transposed digits, short sales incorrectly credited to another similarly named firm, etc.
} 
To assist in comparing short positions across time and firms, we adjust short interest in two ways. First, the exchange reported short sales are not always adjusted for stock splits or stock dividends that occur the same month, so we matched all firms with the CRSP tapes and corrected for these events. Adjusting for stock splits is cumbersome because the effective date of the stock split during a month may be before or after the short interest numbers are reported. Second, as mentioned, we divide each firm's short interest by the number of shares outstanding. 7 This adjustment is important when comparing firms because the number of shares that constitute a significant short interest position differs from firm to firm depending on the shares outstanding. All short interest numbers in this paper are reported as percentages of total shares outstanding.

\section{B. Descriptive Statistics}

Figure 1 plots the time series of short interest data (relative to shares outstanding) for NYSE and Amex firms over the period 1976-2002, and Figure 2 plots the short interest ratios for Nasdaq firms over the period June 1988-December 2002. Four short interest ratios are reported in the figures: the mean, the median, and the $95^{\text {th }}$ and $99^{\text {th }}$ percentiles. The $95^{\text {th }}$ and $99^{\text {th }}$ percentiles are the cutoffs for firms in the top 5 percent and top 1 percent of our sample, ranked by short interest ratio. Two characteristics of the distributions stand out. First, the typical firm in our sample has very little short interest. Even at its peak in 2002, the median firm in Figure 1 on the NYSE-Amex and in Figure 2 on Nasdaq had only one percent of its outstanding shares shorted. While most firms have little or no short interest, a very small number have substantial short interest. An NYSE-Amex firm in the $99^{\text {th }}$ percentile had at least $23 \%$ of its outstanding shares shorted in 2002, and the corresponding firm on Nasdaq had 24\% short.

\footnotetext{
${ }^{4}$ The two sources we use for shares outstanding are CRSP and Compustat. However, these data sources sometimes differ in the number of shares outstanding they report. When the shares outstanding differ, CRSP tends to lag actual shares outstanding when checked against SEC filings. Compustat often sums shares across all classes of common stock. We use shares outstanding from CRSP if both sources are available because their errors are less severe in calculating short interest. Since our errors from CRSP are typically too few shares outstanding, we may include more firms in higher short interest portfolios than there actually are. Any such errors may weaken our results.

${ }^{5}$ While we measure short interest relative to shares outstanding, a more traditional measure, reported in the Wall Street Journal each month, is short interest relative to daily trading volume, known as the days to cover ratio or days short. Which measure is more appropriate partly depends on the question being addressed. If one views short interest as indicative of future buying pressure as short sellers cover their positions, the days to cover ratio is arguably the best measure. But if one views short interest as reflecting the information of informed investors, then the short interest to shares outstanding ratio is arguably the best measure. In any event, these two measures are positively correlated.
} 
Second, short interest increased dramatically from 1976 for NYSE-Amex firms, and from 1988 for Nasdaq firms. This is true for all four measures presented in Figures 1 and 2. Table 1 presents annual averages of short selling both as a percentage of the total shares in the market and as a dollar amount of the total shares sold short. The increase in short sales over time is contemporaneous with the growth of hedge funds, which are much more likely to have large short positions than other types of investors. There is a decline after 1997 for NYSE-Amex firms and after 1998 for Nasdaq firms in the percentage of the market sold short. The percentage short on the Nasdaq exceeds that on the NYSE-Amex from 1992 onwards. After dipping in the late 1990s, short interest ratios resumed their upward trend in 2001-2002.

The dip in the late 1990s corresponds to a period of rapidly rising stock prices. This reduction in the mean short interest ratios as the bubble inflated suggests that "limits to arbitrage" arguments are important (Shleifer and Vishny (1997)). In other words, contrary to the logic of the efficient market hypothesis, the actions of presumably knowledgeable traders in the aggregate did not dampen overreactions caused by other investors.

This point is also made by Lamont and Stein (2004) who examine the correlation between aggregate short interest and market returns. Specifically, they compare monthly Nasdaq short interest ratios and the prior 12-month market return for the period 1995-2002. They report a sample correlation between these variables of -0.54 . Lamont and Stein interpret this result as inconsistent with short sellers moving the aggregate market towards more accurate valuation. In Panel A of Table 2, we report the correlations for our longer period and for NYSE-Amex as well as Nasdaq stocks. We find a dramatically lower correlation of -0.16 between the Nasdaq short interest ratio and 12-month returns over the July 1988-2002 period, and a correlation of -0.13 between the NYSE-Amex short interest ratio and 12-month returns over the 1976-2002 period. Attempting to duplicate Lamont and Stein's result over their time period 1995-2002, we find a negative correlation of -0.47 using Nasdaq data and -0.41 using NYSE-Amex data. Panel A also reports the correlations between short interest and the prior six month and prior one month market returns. These correlations are also negative, but the correlation between the prior month market return and short interest is smaller than that between the twelve month market return and short interest.

\footnotetext{
${ }^{6}$ Brunnermeier and Nagel (2003) report that hedge funds were on average long in technology and Internet stocks during the late 1990s as the bubble inflated, although they started to switch to short positions near the peak.
} 
Because the upward trend in mean short interest ratios suggests that the series may be nonstationary, in Panel B of Table 2 we report the correlation between the change in the percentage of the market sold short and the lagged market return. While these correlations are still negative (with one exception), they reverse the pattern in Panel A. The correlations between market return and change in short interest is larger for one month prior returns than for twelve month prior returns. These results are not surprising since an upward movement in the market raises the costs of many short sellers as they must pay cost of carry and meet margin calls.

To illustrate the types of firms with high short interest, Table 3 lists the names of the 54 firms within the $99^{\text {th }}$ percentile portfolio in December 2002, along with several characteristics of each firm. 51 of the 54 firms have a market capitalization of between $\$ 140$ million and $\$ 1.5$ billion. In other words, almost all of these are small cap stocks, but not micro-cap. Almost all of these stocks were in the Russell 2000 index representing the firms with market caps ranking them 1,001 to 3,000 among the roughly 5,000 domestic operating companies on the NYSE, Amex, and Nasdaq. Furthermore, the industry representation is fairly broad - this portfolio of firms does not subject the holder to excessive concentration in one industry. The combined market cap of these 54 stocks was approximately \$35 billion, only a little more than $10 \%$ of that of General Electric or Microsoft. Table 3 also lists the prior 12-month buy and hold return for the 54 stocks with high short interest, and their market-to-book ratios. Inspection of the list shows that most of the stocks have had negative returns in the prior year, although a few have had big run-ups. As measured by market-to-book ratios, there is a combination of growth and value stocks, with Nasdaq stocks tending to be growth stocks and NYSE-Amex stocks tending to be value stocks.

\section{Research Design}

To empirically investigate whether high short interest stocks underperform relative to the market, we study the relation between short interest and subsequent returns. We form portfolios of highly shorted firms and then calculate returns on these portfolios, reasoning that the strongest relation between short interest and excess returns should exist for firms that have the largest short positions.

We use two approaches to select samples of firms with large short interest positions. The first approach identifies firms based on their short interest relative to other firms. Specifically, each month all firms are ranked according to short interest divided by shares outstanding. The 
firms in the top percentile of short interest comprise the $99^{\text {th }}$ percentile sample, and similarly, the firms in the top five percent comprise the $95^{\text {th }}$ percentile sample. Because the overall level of short interest increased substantially during the 1976-2002 time period, firms entering the high percentile samples during the early part of the time period are likely to have smaller short interest positions than firms entering the sample during the later part of the time period. The second approach to selecting firms with large short interest positions imposes absolute cutoff criteria. Following Asquith and Meulbroek (1995) and Desai et al (2002), we construct three different absolute short interest samples. These samples have short interest greater than or equal to $2.5 \%$, $5 \%$, or $10 \%$ of shares outstanding.

Monthly portfolio returns are calculated from the monthly CRSP tapes, where all returns are from holding long positions. Thus, a negative return is good for short sellers since the stocks sold short decreased in price. This return does not include the higher costs of short selling. That is, it does not include the costs to borrow, the risk of demand loans, and transaction costs associated with heavy portfolio turnover.

Since short interest information is collected and released in the middle of calendar month 0 , we form portfolios at the end of month 0 and report returns beginning in event month $1 . \mathrm{B}_{\text {The }}$ return for the portfolio over inclusion period $[1, \mathrm{~T}]$ is the one-month return for a portfolio of highly shorted firms whose short interest data is released in month 0 , where the firms stay in the portfolio through month T. Alternatively stated, a stock is in the portfolio $[1, \mathrm{~T}]$ if it qualified for inclusion in one or more of the previous $\mathrm{T}$ months. Thus, the monthly portfolio return over inclusion period $[1,1]$ is the return for the calendar month after the firms' short interest places them into a highly shorted portfolio. $Q_{\text {All }}$ of the returns reported in this paper are monthly portfolio returns.

Firms often remain highly shorted for several consecutive months. Table 4 reports the length of time that firms remain in a high short interest portfolio once they have entered it. Table

\footnotetext{
${ }^{7}$ D'Avolio (2002) reports that firms with high short interest ratios are more likely to be on special than other stocks. For these stocks the short interest ratio is likely to be lower than it would be if the supply of shares available for lending was not limited. See the Appendix for institutional procedures on short selling.

${ }^{8}$ The short interest data is from three to five business days before the fifteenth of the month. The release of the information is one or two weeks later. Thus the return in month 0 includes the period prior to the reporting date, as well as a period when the short interest data are not yet known to investors.

${ }^{9}$ The portfolio return for inclusion period $[1,1]$ also contains some information from new short interest data released that month. For example, the [1,1] return for August 1992 (where the portfolio is formed of firms identified by the release of short interest data on July $27^{\text {th }}$ ) will include the market reaction to short interest data that was released on August $21^{\text {st }}$ for the NYSE-Amex and August $26^{\text {th }}$ for Nasdaq.
} 
4 shows that some stocks have high short interest for only one or a few months, but others have high short interest for years. For example, about one third of the firms in a portfolio in a given month are there for only one month, but about half are in for three consecutive months or more. Approximately 11-19\% of the firms, depending on the portfolio, are in the high short interest portfolios for more than one year. This means that the portfolio for inclusion period [1,1] may include stocks that are highly shorted for the first time, as well as stocks that are highly shorted for many previous months. The last column in Table 4 shows that the median number of consecutive months a firm is highly shorted is $2-3$ months. Therefore, the longer the inclusion period, the greater is the number of months a firm is included in the portfolio when it is no longer highly shorted. Finally, Table 4 shows that approximately $70 \%$ of firms are highly shorted for more than one consecutive month.

\section{Empirical Results}

\section{A. Portfolio Returns}

We report returns from July 1988 to December 2002 on the entire sample of NYSEAmex-Nasdaq firms, and after categorizing firms by whether they are traded on the NYSE-Amex or Nasdaq, we also report returns on NYSE-Amex firms from February 1976 to December 2002. In Panel A, we report portfolio returns for firms with short interest ratios of at least $2.5 \%$, and in Panel B, we report portfolio returns for firms whose short interest ratio places them in the $99^{\text {th }}$ percentile. ${ }^{10}$ Table 5 uses two different return measures (EW monthly average raw returns and monthly average intercepts from a four-factor model) over three different inclusion periods $([1,1],[1,6]$, and [1,12]). For portfolios formed after January 2002 and June 2002, the monthly returns on portfolios with inclusion periods of $[1,12]$ and $[1,6]$ are based on less than twelve and six months, respectively.

The abnormal returns are estimated from the four-factor regression model:

$$
r_{p t}-r_{f t}=a+b\left(r_{m t}-r_{f t}\right)+s S M B_{t}+h H M L_{t}+m_{M O M}+e_{p t}
$$

\footnotetext{
${ }^{10}$ We calculated returns for five different high short interest portfolios: $2.5 \%, 5 \%, 10 \%, 95^{\text {th }}$ percentile, and $99^{\text {th }}$ percentile. The two reported portfolio results are representative. Returns from all five portfolios are reported below in Table 6.
} 
where $r_{p t}-r_{f t}$ is the excess return over the risk-free rate on a portfolio in time period $t, r_{m t}-r_{f t}$ is the realization of the market risk premium in period $\mathrm{t}, \mathrm{SMB}_{\mathrm{t}}$ is the return on a portfolio of Small stocks Minus the return on a portfolio of Big stocks in period $t, H_{\mathrm{L}}$ is the return on a portfolio of High book-to-market (value) Minus Low book-to-market (growth) stocks in period t, and $\mathrm{MOM}_{t}$ is the return on a portfolio of prior winners minus the return on a portfolio of prior losers (Fama and French (1993) and Carhart (1997)). The return interval over which winners and losers are measured is the 11 months before month t-1 (i.e., for March 2002, winners and losers are based on returns from March 2001 through January 2002). The monthly factor return realizations are provided by Kenneth French. The intercept is our measure of monthly abnormal performance.

Table 5, Panel A shows that the monthly average raw returns for EW portfolios of stocks with short interest ratios of at least $2.5 \%$ are positive for every inclusion period and for every calendar period. These positive raw returns imply that a trading strategy of being naked short in highly shorted firms is unprofitable. This alone does not indicate that highly shorted stocks are not overvalued. The abnormal returns, measured using a four-factor model, are negative for the majority of EW portfolios reported in columns 4-6. This shows that these firms, even though they have a positive raw return, underperform.

In Panel B of Table 5, we report results for the $99^{\text {th }}$ percentile portfolio. The returns are generally more negative than in Panel A. In Panel B, the monthly average raw returns for all portfolios on the combined NYSE-Amex-Nasdaq stocks are negative for the period July 19882002. The monthly abnormal returns are also negative for this period for both NYSE-Amex and Nasdaq stocks separately. The monthly abnormal returns in columns 4 through 6 are negative as well as for the NYSE-Amex stocks during the 1976-2002 period.

In Table 5, for every reported calendar time period, the abnormal returns are more negative for portfolio inclusion period $[1,1]$ than $[1,6]$ which in turn is more negative than $[1,12]$. The fact that the monthly four-factor intercept shows lower returns for inclusion period [1,1] than either $[1,6]$ or $[1,12]$ suggests that high portfolio turnover may be required to capture the low returns on stocks with high short interest ratios.

In the rest of the paper, we will only report results from the four-factor model and we will only report returns from two inclusion periods: [1,1] and [1,12]. The [1,12] inclusion period, which we use in only one table, is representative of a longer inclusion period and its abnormal 
performance per month is typically smaller than $[1,1]$ and $[1,6]$, but larger than the unreported $[1,24]$ inclusion period.

\section{B. Abnormal portfolio returns for inclusion period [1,1]}

In Table 6, we report the results of four-factor regressions for five portfolios composed of all NYSE-Amex and Nasdaq firms with high short interest over the July 1988-2002 time period. This is the 174 month period that includes both NYSE-Amex and Nasdaq stocks. The portfolio inclusion period is $[1,1]$. In Panels A and B, we report equally weighted results, and in Panels C and $\mathrm{D}$, we report value weighted results.

In Panel A, firms in the five portfolios have short interest ratios during the prior month of at least $2.5 \%, 5.0 \%, 10.0 \%$, or short interest ratios that place them in the $95^{\text {th }}$ or $99^{\text {th }}$ percentile of all firms. Inspection of the EW results in Panel A shows that all five portfolios have statistically significant negative intercepts, with the high short interest portfolios underperforming by anywhere from -48 basis points to -125 basis points per month. On an annualized basis, this is $6 \%$ to $15 \%$ per year. The more heavily shorted are the firms in a portfolio, the more negative is the performance: the portfolio where all firms have short interest ratios of at least $10 \%$ has more underperformance than the $5.0 \%$ portfolio, which in turn does worse than the $2.5 \%$ portfolio. Similarly, the $99^{\text {th }}$ percentile portfolio has more extreme underperformance than the $95^{\text {th }}$ percentile portfolio.

The abnormal returns on the portfolios in Table 6 Panel A are not independent because some firms appear in more than one portfolio. For example, the $2.5 \%$ portfolio includes all stocks with a short interest ratio of $2.5 \%$ or higher, including those with a short interest ratio of $5.0 \%$ or more. In principle, firms with short interest ratios between $2.5 \%$ and $4.9 \%$ could have zero abnormal returns and yet the $2.5 \%$ portfolio, as measured, could significantly underperform. To look at the marginal effects, we examine in Panel B three additional truncated portfolios: portfolios containing firms with a short interest ratio greater than or equal to $2.5 \%$ but less than $5 \%$, greater than or equal to $5 \%$ but less than $10 \%$, and greater than or equal to the $95^{\text {th }}$ percentile but less than the $99^{\text {th }}$ percentile. While the greater than $2.5 \%$ portfolio in Panel A has an intercept of -48 basis points and a t-statistic of -2.79 , the $2.5-4.9 \%$ portfolio in Panel B has an intercept of only -28 basis points with a t-statistic of only -1.58 . Similarly, the greater than $95^{\text {th }}$ percentile

\footnotetext{
${ }^{11}$ We calculate returns for the inclusion periods $[1,1],[1,3],[1,6],[1,12]$, and $[1,24]$ and the results support the general pattern described in Table 5 .
} 
portfolio intercept is -54 basis points $(\mathrm{t}=-2.67)$, while the $95-98.9^{\text {th }}$ percentile intercept is only 36 basis points ( $\mathrm{t}=-1.74)$. In every $\mathrm{EW}$ case, the truncated high short interest portfolio is less negative than the corresponding untruncated portfolio and is less significant. These results demonstrate that the negative performance of some of the less restrictive untruncated portfolios is driven by the underperformance of the firms in the more heavily shorted portfolios.

In contrast to the statistically significant negative abnormal returns for the EW results reported in Panel A, the VW results reported in Panel C and D show no reliable underperformance. Indeed, several of the VW portfolios have positive intercepts. As in Panel A, the more extreme portfolios ( $10 \%$ and $99^{\text {th }}$ percentile) have lower intercepts than the less extreme portfolios $\left(2.5 \%\right.$ and $95^{\text {th }}$ percentile). Panel D of Table 6 reports coefficients for three VW truncated portfolios. As with the EW results, the truncated portfolios have more positive returns than the corresponding untruncated portfolios. The difference between the EW and VW results suggests that large firms with high short interest do not reliably underperform.

Examination of the factor loadings (the slope coefficients) in Table 6 Panels A-D reveals that firms with high short interest tend to have relatively high systematic risk, tend to positively covary with small firms, tend to be tilted towards growth stocks when value weighted portfolios are used, and tend to have negative momentum. Table 7 compares median size and market-tobook ratios of highly shorted stocks to the rest of the market. We now substitute the truncated portfolios, $2.5-4.9 \%, 5-9.9 \%$, and $95-98.9^{\text {th }}$ percentile for the untruncated portfolios greater than $2.5 \%$, greater than $5 \%$, and $95^{\text {th }}$ percentile in the tables. This is so each of our three absolute cutoff portfolios and two relative portfolios are distinct and there is no overlap of firms within the absolute or relative rankings. The median market cap of highly shorted firms in Panel A is noticeably higher than the median for other firms, reflecting the paucity of micro-cap stocks in our portfolios. This is consistent with Table 3, which lists the stocks and their characteristics in the $99^{\text {th }}$ percentile sample for December 2002. Panel B shows that the median highly shorted firm is a growth firm, as measured by its market-to-book ratio, consistent with Dechow et al (2001).

\footnotetext{
${ }^{12}$ Boehme et al report four-factor regression intercepts for equally weighted portfolios of firms with high short interest ratios. Their large firm portfolio has approximately 1,500 stocks in it during the portion of their sample period, 1993-July 1999, in which Nasdaq stocks are included. The poor performance of mid-cap stocks offsets the relatively good performance of large-cap stocks, and thus they fail to pick up the relatively high returns on large stocks with high short interest ratios that our VW portfolios uncover.
} 
In Table 8, we examine whether the performance of firms with high short interest differs between NYSE-Amex firms and Nasdaq firms during the July 1988-December 2002 period. Five truncated samples are presented: $2.5-4.9 \%, 5-9.9 \%, 10 \%, 95-98.9^{\text {th }}$ percentile and $99^{\text {th }}$ percentile. In constructing the NYSE-Amex portfolios and Nasdaq portfolios using the $95-98.9^{\text {th }}$ and $99^{\text {th }}$ percentiles, we use population-specific short interest ratio cutoffs, whereas when we report combined NYSE-Amex-Nasdaq results, as in Table 6, the same absolute cutoffs are used for all stocks in a given month. For example, as shown in Figures 1 and 2, in December 2002 the $99^{\text {th }}$ percentile cutoff for NYSE-Amex firms is about $23 \%$, but for Nasdaq firms, it is about $21 \%$. These are the cutoffs that we use in Table 8 , but the Table 6 cutoff would be about $22 \%$, applied to all firms.

In Panel A of Table 8, we report four-factor regression results for EW portfolios of NYSE-Amex firms over the July 1988-December 2002 period. For all five portfolios, there is statistically significant negative abnormal performance ranging from -41 basis points per month to -146 basis points per month. As in Tables 5 and 6, this underperformance is more extreme, the more heavily shorted the firms in the portfolio.

In Panel B, we report the results of four-factor regressions for EW portfolios of Nasdaq stocks with high short interest. In contrast to the NYSE-Amex results, the underperformance for Nasdaq stocks is not always statistically significant at conventional levels. Only two of the five intercepts are significant at the $10 \%$ level, although all of the point estimates are negative, ranging from -14 to -127 basis points per month. The Nasdaq results also do not follow a monotonic pattern, since the 5-9.9\% truncated portfolio has a more negative intercept than the $10 \%$ portfolio.

While the systematic risk in both panels is high and the momentum factors are both negative, some of the factor loadings differ substantially between the Panel A NYSE-Amex results and the Panel B Nasdaq results. Specifically, the EW Nasdaq portfolios are more sensitive to small stock movements, and the NYSE-Amex portfolios move with value stocks, whereas the Nasdaq portfolios move with growth stocks. The reliably positive coefficients on HML for NYSE-Amex stocks are somewhat surprising, given that our Table 7 and Dechow et al (2001) report that NYSE-Amex firms with high short interest tend to be growth firms. 13

\footnotetext{
${ }^{13}$ The difference in conclusions about whether highly shorted NYSE-Amex firms tend to be growth firms (the conclusion based on the medians) or value firms (the conclusion based on the slope coefficients) has to do with differences in the weighting schemes. The Fama-French HML factor is constructed by giving equal weights to the
} 
In Panels $\mathrm{C}$ and $\mathrm{D}$ of Table 8, we report value weighted results for portfolios of NYSEAmex and Nasdaq firms, respectively. In contrast with the EW results in Panels A and B, none of the VW portfolio intercepts have a t-statistic of -2.0 or less. In fact, half of the VW portfolio intercepts are positive and half are negative.

The point estimates in Table 8 Panel B for our truncated portfolios of EW Nasdaq stocks during July 1988-December 2002 are less negative and significant than those reported for untruncated portfolios by Desai et al (2002) for their sample period of July 1988-December 1994. To investigate whether the difference in results is sample period specific, we next partition our sample by markets and time periods. In particular, we examine the six and one-half year period June 1988-1994 for Nasdaq versus NYSE-Amex stocks since this allows us to compare our results directly with Desai et al. We also report results for the twelve and a half year period 1976-June 1988 (for which we only have NYSE-Amex stocks) and the eight-year period 19952002.

Table 9 reports the EW and VW four factor model intercepts for the 2.5-4.9\% truncated and $99^{\text {th }}$ percentile portfolios divided by market and subperiod and shows that calendar period and markets do matter. To avoid overburdening the reader, we do not report the results on the 5$9.9 \%, 10 \%$, and $95-98.9^{\text {th }}$ percentile portfolios in the table, but they generally follow the pattern discussed above that the greater the short interest ratio, the more negative the result. For all three panels of the table, if the $2.5-4.9 \%$ and $99^{\text {th }}$ percentile portfolios are both significantly negative, then the three unreported truncated portfolios also have significantly negative intercepts. There are three non-overlapping subperiods (1976- June 1988, July 1988-1994, and 1995-2002) and two combined periods (1976-2002 and July 1988-2002) presented in Table 9. The earliest subperiod is only available for NYSE-Amex stocks. We will first discuss the EW and VW subperiod results by panel and then the combined period results.

The NYSE-Amex-Nasdaq results reported in Panel A show statistically significant negative EW intercepts for the $2.5-4.9 \%$ and $99^{\text {th }}$ percentile portfolios during the July $1988-1994$ subperiod. The VW results for the same subperiod are significantly negative only for the $99^{\text {th }}$

returns on a value weighted portfolio of small value firms and a value weighted portfolio of large value firms, and then subtracting the returns on two growth stock portfolios that are weighted in a similar manner. The effect of this (which is done to minimize the correlation of the HML factor with the size factor) is to overweight the influence of small growth stocks on Nasdaq. Consequently, since NYSE-Amex stocks are tilted towards value relative to Nasdaq stocks, even growth stocks on the NYSE-Amex appear to have a value tilt with respect to the HML factor. 
percentile and the 10\% (not reported in the table) portfolios. For the 1995-2002 subperiod, the only significant abnormal return, reported or not, is for the EW $99^{\text {th }}$ percentile portfolio.

Examining the NYSE-Amex results in Panel B for the 1976-June 1988 subperiod, none of the EW or VW portfolio intercepts are negative and statistically significant. In the subperiod July 1988-1994, the EW $99^{\text {th }}$ percentile portfolio intercept is significantly negative, but the EW 2.5-4.9\% portfolio intercept is not. This latter portfolio is the only one of the five calculated EW portfolios not significantly negative during this subperiod. During this same subperiod, only the VW $10 \%$ and $99^{\text {th }}$ percentile portfolio intercepts are negative and statistically significant. For the subperiod $1995-2002$, the EW $2.5-4.9 \%$ and $99^{\text {th }}$ percentile portfolios both have significantly negative abnormal returns as reported in the table, although the VW results do not.

Inspection of the Nasdaq results in Table 9 Panel C shows significantly negative EW abnormal returns for the 2.5-4.9\% and $99^{\text {th }}$ percentile portfolios for the July 1988-1994 subperiod. For the VW results, only the $99^{\text {th }}$ percentile portfolio intercept is negative and statistically significant. During the $1995-2002$ subperiod, the EW $99^{\text {th }}$ percentile portfolio is the only portfolio that has statistically significant negative returns.

Examining next the combined periods, Panel B reports that both EW NYSE-Amex portfolio intercepts are significantly negative for July 1988-2002 and 1976-2002. The $99^{\text {th }}$ percentile portfolio for 1988-2002 is the only VW portfolio significantly negative during the two combined periods. For Nasdaq stocks in Panel C, during July 1988-2002 the EW and VW $99^{\text {th }}$ percentiles are the only portfolio intercepts that are negative and significant. For the entire sample of NYSE-Amex-Nasdaq stocks in Panel A during 1988-2002, the 2.5-4.9\% EW portfolio intercept is the only one of the five EW portfolios that is not significant. During 1976-2002, all EW portfolio intercepts are significantly negative. None of the VW portfolio intercepts in Panel A are negative and significant for either combined period.

These results show that during the subperiod July 1988-1994 both NYSE-Amex and Nasdaq EW portfolios exhibited significantly negative abnormal returns for all but the least restrictive NYSE-Amex portfolios. In addition, for this subperiod the most highly shorted VW portfolios are also negative and significant for both NYSE-Amex and Nasdaq firms. This is by far the most universally negative subperiod we examine and is of course the time period that Desai et al (2002) investigate. Comparing our truncated EW 2.5-4.9\% portfolio of Nasdaq stocks 
to their untruncated EW $2.5 \%$ portfolio, our four factor model intercept of -89 basis points in Panel $\mathrm{C}$ shows more underperformance than the -76 basis points that they report. 14

For the earliest subperiod 1976-June 1988 none of the EW or VW NYSE-Amex portfolio intercepts are significantly negative. For the 1995-2002 subperiod, all the EW NYSE-Amex portfolios intercepts are significantly negative, but none of the VW ones are. For the same subperiod, only the EW $99^{\text {th }}$ percentile Nasdaq portfolio intercept is significantly negative. Thus, the earliest subperiod does not have reliably negative intercepts for NYSE-Amex portfolios and the latter subperiod, except for the most highly shorted portfolio, is not negative for Nasdaq firms. The middle subperiod has negative intercepts for both NYSE-Amex and Nasdaq. The combined periods reflect these results, but the results for the middle period, July 1988-1994, are so strong that the combined periods July 1988-2002 and 1976-2002 are negative and statistically significant for most EW portfolio intercepts across all markets in Panel A of Table 9.

Since the patterns in abnormal returns vary so much over time, we next compute regressions estimated over rolling 48-month periods. Figures 3 and 4 plot the four-factor model intercepts for the EW $99^{\text {th }}$ percentile portfolios by market for rolling 48 month calendar time periods with $5 \%$ two-tail confidence intervals. For example, the value $-2.3 \%$, plotted and labeled May 1992, in Figure 3 represents the four-factor model intercept for the EW $99^{\text {th }}$ percentile NYSE-Amex portfolio estimated over the time period June 1988 to May 1992. Figures 3 and 4 reinforce and extend the results in Tables 8 and 9. The 48 month VW rolling regressions, not shown here, have less negative and significant intercepts than the EW rolling regressions, as expected from Tables 8 and 9. It should be noted that the rolling intercepts are not independent, i.e. for each month, each 48 month portfolio contains 47 of the same observations as the portfolio before and after it.

In summary, Table 8 shows that EW high short interest portfolios underperform the market for both combined markets and for NYSE-Amex and Nasdaq separately. However, Table 9 and Figures 3 and 4 show that this result does not hold for all calendar periods. Most

\footnotetext{
${ }^{14}$ In unreported results, our untruncated EW Nasdaq 2.5\% portfolio has a negative abnormal return of -103 basis points. Our stronger results may be due to extensive data cleaning which would reduce any errors in variables bias. In addition, our empirical results consistently have larger standard errors than in Desai et al (2002), even when we use untruncated portfolios and methodology that is identical to their Table 3 methodology. Our t-statistic implies a monthly standard error of 31 basis points, whereas their t-statistic implies a monthly standard error of 23 basis points. On pp. 2275 and 2277 they report the point estimates and t-statistics from additional robustness checks, with implied standard errors of an implausibly low 3-6 basis points per month. The t-statistics on their robustness checks are apparently overstated by a factor of almost ten.
} 
importantly, the June 1988-1994 period is among the strongest period of underperformance, particularly for the Nasdaq stocks that Desai et al (2002) analyze.

\section{Abnormal portfolio returns for inclusion period [1,12]}

In Tables 6, 8, and 9 firms with high short interest enter a portfolio in the calendar month immediately after they meet the inclusion criteria, and are removed from the portfolio in the month after their short interest ratio falls below the portfolio's threshold. We next calculate returns for inclusion period $[1,12]$ where firms stay in a portfolio until 11 months have elapsed after their short interest ratio drops below the threshold (e.g., a 2.5\% short interest ratio for the $2.5 \%$ portfolio). If, within 10 months after falling below the inclusion threshold, a stock's short interest ratio rises to qualify it for inclusion again, its time in the portfolio is extended. In other words, for calendar month $\mathrm{t}$, the firms in a high short interest portfolio are all firms whose short interest ratio qualified it for inclusion in at least one month during the prior 12 months. If a firm is delisted, it is no longer part of the portfolio. The purpose of using this longer portfolio inclusion period is to see if abnormal performance persists. Unless there is an early delisting, all stocks in the portfolio are retained in the portfolio for at least one year, as contrasted with the one-month minimum in Tables 6,8 , and 9.

The pattern of intercepts from the four-factor regressions using monthly returns for inclusion period [1,12], although not reported here, are similar, but not as strong as in Table 9. For example, for the period 1988-2002 across all markets, the EW $99^{\text {th }}$ percentile portfolio intercept for the $[1,1]$ inclusion period is $-1.25(\mathrm{t}=-4.42)$ while for the $[1,12]$ inclusion period, it is $-0.77(\mathrm{t}=-2.84)$. This suggests that negative abnormal returns revert towards zero after a firm's short interest ratio drops. This is consistent with the old conventional wisdom that returns are high when short sellers are covering their positions. These results are at odds with those reported in Desai et al (2002), where there is no perceptible difference in abnormal returns whether a stock is deleted from a portfolio as soon as a stock no longer qualifies for inclusion, or whether 12 months pass. Comparison of the [1,1] and [1,12] results find that the 1988-1994 subperiod has the longest persistent of abnormal returns of any subperiod for both NYSE-Amex and Nasdaq firms. Thus, it again appears that Desai et al (2002) July 1988-1994 Nasdaq findings do not generalize. The rapid drop off in underperformance once short interest ratios fall has an important implication: high portfolio turnover is required to profit from the underperformance. 


\section{Arbitrage vs. Valuation Shorts}

A stock can have a high short interest ratio for several reasons. Thus far we have assumed that stocks have high short interest because investors considered them to be overvalued. We refer to these as valuation shorts. But many short positions are established as part of an arbitrage strategy, with convertible bond arbitrage and takeover arbitrage among the most common motivations. In a typical convertible bond arbitrage, an investor views the conversion option on the convertible to be underpriced, and buys the convertible while simultaneously shorting the stock. The position is unwound when the convertible price rises so that the conversion option is no longer underpriced, a process that might take many months. In a typical takeover arbitrage, the investor shorts the acquiring firm and goes long in the takeover target if the takeover is a stock-for-stock exchange. In cash-for-stock takeovers, risk arbitrageurs typically just take an unhedged long position in the target. Because few takeovers drag on for long periods, takeover arbitrage frequently involves positions held for at most a few months before being unwound.

Of course, a firm might have a high short interest ratio because there is both valuation shorting and arbitrage shorting taking place simultaneously. Unfortunately, we cannot identify these situations precisely. To simplify things, we categorize firms that either have a convertible bond outstanding or are making an acquisition as arbitrage shorts. As a crude measure we take all firms with convertible bonds outstanding from Compustat balance sheet information and consider them arbitrage shorts. Panel A of Table 10 shows that firms with convertible bonds outstanding are much more likely to have high short interest ratios than random firms. Over the 1988-2002 period, 9.6\% of all firms in a given month had a convertible bond outstanding. In the $99^{\text {th }}$ percentile portfolio, $25.7 \%$ of firms had a convertible bond outstanding for an average month. Thus, stocks with convertible bonds are roughly three times as likely to be in high short interest portfolios as random stocks. This finding supports our assumption that this crude measure may identify arbitrage shorting.

Categorizing our sample as either arbitrage or valuation shorts and re-estimating the EW four-factor portfolio model over the period 1988-2002 yields the results in Panels B, C, and D of Table $10 .{ }^{15}$ The pattern of four-factor model intercepts for EW portfolios of stocks with high

\footnotetext{
${ }^{15} \mathrm{We}$ also investigated arbitrage portfolios involving merger arbitrage from a proprietary database. The results, which we are not allowed to report here, are qualitatively similar to those for our convertibles.
} 
short interest (using the $2.5-4.9 \%$ and $99^{\text {th }}$ percentile portfolios) shows that abnormal returns on arbitrage shorts are less negative and less statistically significant than valuation shorts. Thus, Table 10 suggests that the negative abnormal returns on our high short interest portfolios are driven more by valuation shorts than by arbitrage shorts. Moreover, Panel A clearly shows, even though our methodology does not allow us to identify when arbitrage shorting takes place, there is more than one reason for shorting stocks.

\section{Conclusion and Implications}

In recent years the empirical literature on short selling shows that stocks with high short interest ratios underperform and that short interest ratios have increased over time (Asquith and Meulbroek (1995) and Desai et al (2002)). This literature also documents that short sellers target firms selling at high multiples (Dechow et al (2001)), that the stocks with the worst subsequent performance are those with both high short interest and large differences of opinion (Boehme $e t$ al (2002)), and that there is a large negative correlation between market performance and short interest (Lamont and Stein (2004)).

The problem with this literature is that it is based on short time periods and/or incorrect and incomplete analysis. In this paper, we show that while equally weighted portfolios of stocks with high short interest ratios reliably underperformed over the 1976-2002 period, value weighted portfolios did not. In addition, by using truncated (non-overlapping) portfolios, we show that the highest short interest stocks drive some of the results of earlier work. Moreover, we show that 2002 has the highest levels of short interest ever recorded. While there is a negative correlation between short interest and trailing market performance for our whole period, it is weak compared to the 1995-2002 period that Lamont and Stein examine. Furthermore, the correlation between changes in short interest and trailing market performance, not reported elsewhere, is large and significant for the one month prior market return.

We find that the underperformance of high short interest firms is fairly brief, and only rapid portfolio turnover allows us to realize this underperformance. We also examine whether high short interest is based only on valuation concerns and find that convertible bond arbitrage is a major reason for high short interest as well. Finally, we show that the performance of high short interest NYSE-Amex stocks is more severe and consistent than for their Nasdaq 
counterparts over the period July 1988-2002, and that small cap firms make up a large portion of the firms that are highly shorted.

Equally weighted portfolios of heavily shorted stocks underperform relative to a fourfactor model specification during the 1976-2002 and July 1988-2002 period. A portfolio strategy of shorting these stocks should therefore yield positive abnormal returns over this period. Whether short sellers in fact can profit from this strategy depends on implementation costs, including some unique to short selling. First, short sellers must locate the stock to borrow, which can sometimes be difficult. Second, even after locating the stock, they must stand ready to repay the loan at any time. Hence, short sellers face the risk that their positions may be terminated at a less than optimal time. Most importantly, as other studies show (D’Avolio (2002), Geczy, Musto, and Reed (2002), and Jones and Lamont (2002)), many of the stocks with high short interest are on special, which increases the cost of shorting, due to the rebate rate that must be paid. Thus, active trading strategies are likely to be subject to an implementation shortfall relative to the returns that we report.

Whether or not short sellers can profit from a short selling strategy, the finding that heavily shorted stocks underperform the market has other important investment implications. An investor selecting stocks for a portfolio should avoid stocks with a high short interest ratio. If an investor already owns a stock that develops sustained high short interest, the clear and strong advice is to sell the stock immediately, unless adverse tax consequences are present. The number of stocks in any month that must be avoided or sold is small, however. As shown in Table 6, the abnormal return for the $99^{\text {th }}$ percentile EW portfolio is a significantly negative 125 basis points per month over the 1988-2002 period, and the abnormal return for the 95-98. $9^{\text {th }}$ percentile EW portfolio is a marginally significant 36 basis points per month. Therefore, following the advice to stay away from highly shorted stocks only requires investors to avoid a few percent of all stocks in the market each month, although diligence is required to track the changing composition of these stocks.

Our findings also have implications on whether hedge funds produce positive abnormal returns. A common assertion is that one way that hedge funds add value is because of their ability to take short positions in overvalued equities, whereas most mutual funds are restricted to long-only positions. Our results indicate that the only class of stocks that reliably produce negative abnormal returns is that of small cap firms with extremely high short interest ratios. At 
the end of 2002, however, firms in the $99^{\text {th }}$ percentile had an aggregate market capitalization of only $\$ 35$ billion. If the largest firm among these is excluded, the total market cap drops to $\$ 30$ billion. If the average short interest ratio for these stocks is $40 \%$, only $\$ 12$ billion in short positions is available for these firms. Given that the hedge fund industry is estimated to have about $\$ 600$ billion under management (albeit not all in domestic equities), our findings suggest that the average hedge fund is unlikely to be creating significant value from short selling stocks. 


\section{References}

Asquith, Paul, and Lisa Meulbroek (1995) "An Empirical Investigation of Short Interest," unpublished M.I.T. working paper.

Boehme, Rodney D., Bartley R. Danielsen, and Sorin M. Sorescu (2002) "Short-sale Constraints and Overvaluation," unpublished Texas A\&M working paper.

Brent, A., D. Morese, and E. K. Stice (1990) "Short Interest: Explanations and Test." Journal of Financial and Quantitative Analysis 25, 273-289.

Brunnermeier, Markus, and Stefan Nagel (2003) "Hedge Funds and the Technology Bubble," Journal of Finance, forthcoming.

Carhart, Mark (1997) “On Persistence in Mutual Fund Performance,” Journal of Finance 52, 5782.

D'Avolio, Gene (2002) “The Market for Borrowing Stock” Journal of Financial Economics 66, 271-306.

Dechow P., Hutton A., Meulbroek L. and R. Sloan (2001) "Short-sellers, Fundamental Analysis and Stock Returns," Journal of Financial Economics 61, 77-106.

Desai, Hemang, K. Ramesh, S.R. Thiagarajan, and B. V. Balachandran, "An Investigation of the Informational Role of Short Interest in the Nasdaq Market," Journal of Finance 57, 22632287.

Diamond D. and R. Verrecchia (1987) "Constraints on Short-Selling and Asset Price Adjustment to Private Information.” Journal of Financial Economics 18, 277-311.

Fama, E., and K. French (1993) "Common risk factors in the returns on stocks and bonds," Journal of Financial Economics 33, 3-56.

Figlewski S. (1981) "The Information Effects of Restrictions on Short Sales: Some Empirical Evidence," Journal of Financial and Quantitative Analysis 16, 463-476.

Figlewski S. and G. Webb (1993) "Options, Short Sales, and Market Completeness," Journal of Finance 48, 761-777.

Geczy, C. C., D. K. Musto, and A. V. Reed (2002) "Stocks are Special Too: An Analysis of the Equity Lending Market," Journal of Financial Economics 66, 241-269.

Gopalan, Mohanaraman, 2003. "Short constraints, difference of opinion and stock returns," unpublished Duke University working paper.

Jones, Charles M., and Owen Lamont (2002) "Short-sale Constraints and Stock Returns," Journal of Financial Economics 66, 207-239. 
Lamont, Owen (2002) “Go Down Fighting: Short Sellers vs Firms” Unpublished University of Chicago working paper.

Lamont, Owen, and Jeremy C. Stein (2004) "Aggregate Short Interest and Market Valuations," Forthcoming, American Economic Review.

Miller, Ed (1977) "Risk, Uncertainty, and Divergence of Opinion,” Journal of Finance 32, 11511168.

Ofek, Eli, Mathew Richardson, and Robert F. Whitelaw (2003) "Limited Arbitrage and Short Sales Restrictions: Evidence from the Options Markets," Journal of Financial Economics, forthcoming.

Rubinstein, Mark (2004) “Great Moments in Financial Economics: III. Short-Sales and Stock Prices," Journal of Investment Management 2.

Senchack, A.J., Jr., and Laura T. Starks (1993) "Short-Sale Restrictions and Market Reaction to Short-Interest Announcements" Journal of Financial and Quantitative Analysis 28, 177194.

Shleifer, A., and R. Vishny (1997) “The Limits to Arbitrage,” Journal of Finance 52, 35-55.

Woolridge, J.R., and A. Dickinson (1994) “Short Selling and Common Stock Prices.” Financial Analysis Journal, 20-28. 


\section{Appendix. Short Selling Procedures}

A short sale is a sale of borrowed stock, and is the most direct way for an investor to bet that a stock price will decrease. Regulatory "prudent investor rules," however, prohibit many institutional investors, particularly banks, pension funds, and insurance companies, from short selling. These rules primarily exist because the risk-return profile of a short position is very different from that of a long position. The maximum loss on a long position is the amount invested (if the security price goes to zero) while the maximum gain is unlimited. The maximum gain on a short position is $100 \%$ of the proceeds (if the security price goes to zero), but the potential loss is unlimited.

Investors selling short also face more stringent restrictions than investors going long. To execute a short sale, the seller must borrow the stock through a broker or an investor who owns the stock. The broker secures the stock either from another investor's margined account at the brokerage house, or from a large institutional investor, like a pension fund or depository bank, or from another broker-dealer. $\frac{16}{16}$ The Securities and Exchange Commission (SEC) requires that all short sales be marked as such, and also requires that short sales on the NYSE, Amex, and Nasdaq be made only on a "plus tick" or a "zero plus tick". That is, a short sale can only occur at a price above the last sale price or at a price equal to the last sale price if the most recent price movement was positive.

The proceeds from a short sale are not available to the short seller, but instead are escrowed as collateral for the owner of the borrowed shares. While large short sellers may receive interest on the proceeds of the short sale, small short sellers usually receive no interest. If the lenders of the stock are institutional investors, they receive the proceeds of the sale, but pay interest to the broker on these proceeds. The lending broker collects the spread between the interest rebate given to the short seller and the interest charged to stock lenders on the rebate. These interest rates vary inversely with the difficulty in locating the borrowed shares. If the shares are not hard to borrow, the Fed Funds rate minus one-quarter percent represents a typical rebate to short sellers; Fed Funds minus one-eighth percent is a typical rate that lenders must pay. For stocks in short supply, borrowers receive no rebate, and they often pay a premium; likewise, lenders would not pay interest and may collect rent on the proceeds of difficult to

\footnotetext{
${ }^{16}$ Certain market makers are allowed to sell a stock short without borrowing shares. This exemption is currently the subject of a proposed SEC rule that would eliminate it.
} 
borrow stocks. When the source for the borrowed stocks is a retail margined account, not an institutional investor, the owners of the stock may never know that they have lent out the stock, and they do not receive the proceeds of the sale or any interest thereon.

In addition to the proceeds which remain as collateral, Regulation $\mathrm{T}$ requires that a short seller deposit 50 percent of the market value of the shorted sales as a margin requirement (the Fed Reserve sets Regulation $\mathrm{T}$ and the percentage may vary over time). If the price of the shorted stock rises, the short seller faces a margin call, and must deposit more funds. The short seller may use the market value of their non-margined long positions or may deposit interest-bearing treasury securities (and keep the interest) to meet margin requirements. While a short position is open, the short seller faces the additional cost of reimbursing the owner of the security for any dividends the stock may accrue. The tax treatment of short sales may also make them more costly than long positions. Unlike profits from long sales, profits from short sales are subject to short term capital gains, no matter how long the short position is held.

One distinguishing feature of the market for borrowing and lending equities that affects the risk of a short position is the term of the security's loan. All loans are "demand loans": the owner of the borrowed shares may at any time decide to sell the security, so the borrower must stand ready to replace the shares if required. If the short seller is not ready to close out their position, they will seek to borrow the shares from another source. If all available margined shares are already loaned out, and the short seller's broker cannot locate the desired shares from an institutional owner, the short seller must purchase the shares on the open market to cover the loan (this is known as a "short squeeze"). Short sellers try to manage the risk of a short squeeze by discovering the source of the borrowed shares. The broker will sometimes tell large borrowers the source of the borrowed shares, which may yield some information regarding the probability of a short squeeze. For instance, market index funds are less likely to sell their shares than retail investors or actively managed funds.

While borrowing stock to short is costly and risky, lending stock to short sellers can be safe and profitable. The combination of keeping the cash proceeds of the sale, the $50 \%$ margin requirement, and daily margin calls make the risk of lending stock very small. Any brokerage or financial intermediary may lend stock to short sellers, but the largest participants in this market are retail brokerage houses, brokerages that do large scale stock clearing operations for other firms, and banks that serve as security depositories. All three have access to large inventories of 
stock as a normal part of their business which they lend out to increase profitability. As short selling increased in the nineties, some investment banks began to contact fiduciaries who held large amounts of stock, i.e. pension funds, insurance companies, and university endowments to contract with them so the investment bank has access to their stock portfolios for lending purposes. The investment bank often pays a flat annual fee for access to any stock in the portfolio. This agreement does not restrict the lender's trading strategy in any way.

The costs and risks of short sales outlined above suggest that the options market would allow short sellers to establish similar positions with fewer costs and risks. Hedge fund managers and other practitioners involved in short selling maintain that they can not effectively use the options market. In interviews, they repeatedly claimed that the options market provides less liquidity and is more expensive than the short sales market when trying to establish a large position. Few investors, they assert, are willing to write large amounts of puts on an individual stock without hedging themselves. An important part of the hedge when writing a put is to short the stock. Attempts to buy puts on a hard-to-borrow stock therefore drive up the demand for loans of the stock, and thereby increase the price of the option. 


\section{Table 1}

\section{Summary Statistics: Aggregate Annual Characteristics of Short-selling}

The annual averages are equally weighted averages of the 12 months during the year, except for Nasdaq in 1988 when the data starts in June (7 months) and in 1990 when data for the months of February and July are missing (10 months).

\begin{tabular}{|c|c|c|c|c|}
\hline \multirow[b]{2}{*}{ Year } & \multicolumn{2}{|c|}{ NYSE-Amex } & \multicolumn{2}{|c|}{ Nasdaq } \\
\hline & $\begin{array}{c}\% \text { of Market } \\
\text { Short }\end{array}$ & $\begin{array}{l}\text { Amount Sold } \\
\text { Short } \\
\text { (in \$billions) }\end{array}$ & $\begin{array}{c}\% \text { of Market } \\
\text { Short }\end{array}$ & $\begin{array}{l}\text { Amount Sold } \\
\text { Short } \\
\text { (in \$billions) }\end{array}$ \\
\hline 1976 & 0.33 & 2.5 & & \\
\hline 1977 & 0.32 & 2.4 & & \\
\hline 1978 & 0.41 & 3.2 & & \\
\hline 1979 & 0.40 & 3.5 & & \\
\hline 1980 & 0.43 & 4.5 & & \\
\hline 1981 & 0.44 & 5.0 & & \\
\hline 1982 & 0.70 & 7.5 & & \\
\hline 1983 & 0.64 & 9.3 & & \\
\hline 1984 & 0.60 & 8.6 & & \\
\hline 1985 & 0.69 & 11.3 & & \\
\hline 1986 & 0.81 & 16.6 & & \\
\hline 1987 & 0.80 & 18.7 & & \\
\hline 1988 & 0.69 & 14.8 & 0.30 & 1.0 \\
\hline 1989 & 0.72 & 18.2 & 0.35 & 1.3 \\
\hline 1990 & 0.74 & 18.4 & 0.54 & 1.7 \\
\hline 1991 & 0.71 & 20.9 & 0.64 & 2.6 \\
\hline 1992 & 0.77 & 25.5 & 1.45 & 7.6 \\
\hline 1993 & 0.87 & 32.4 & 1.68 & 11.0 \\
\hline 1994 & 1.13 & 43.9 & 1.92 & 14.3 \\
\hline 1995 & 1.31 & 60.2 & 2.03 & 19.4 \\
\hline 1996 & 1.35 & 77.4 & 2.23 & 28.7 \\
\hline 1997 & 1.56 & 114.8 & 2.46 & 40.2 \\
\hline 1998 & 1.53 & 137.6 & 2.73 & 56.5 \\
\hline 1999 & 1.28 & 131.4 & 2.41 & 78.4 \\
\hline 2000 & 1.23 & 130.9 & 2.30 & 114.0 \\
\hline 2001 & 1.52 & 153.7 & 2.67 & 75.1 \\
\hline 2002 & 1.72 & 153.4 & 2.97 & 63.9 \\
\hline
\end{tabular}


Table 2

\section{Sample Correlations Between Aggregate Short Interest Ratios and Lagged Market Returns}

Table 2 reports sample correlations of the percentage of the market sold short with the nominal return on the CRSP value weighted NYSE-Amex-Nasdaq market index. The p-values, which assume independence, testing the hypothesis that the correlation is 0 are reported in parentheses. Panel A presents the correlation with the percentage of the market sold short, while Panel B presents the correlation with the change in the percent of the market sold short.

Panel A: Correlations with \% market short

\begin{tabular}{ccccc} 
& Time Period & $\begin{array}{c}\text { 1-month lag } \\
\text { return }\end{array}$ & $\begin{array}{c}\text { 6-month lag } \\
\text { return }\end{array}$ & $\begin{array}{c}\text { 12-month lag } \\
\text { return }\end{array}$ \\
\hline \multirow{2}{*}{ NYSE-Amex } & $1976-2002$ & -0.05 & -0.10 & -0.13 \\
& & $(0.38)$ & $(0.08)$ & $(0.02)$ \\
& $7 / 1988-2002$ & -0.11 & -0.19 & -0.18 \\
& & $(0.16)$ & $(0.01)$ & $(0.02)$ \\
& $1995-2002$ & -0.21 & -0.35 & -0.41 \\
& & $(0.04)$ & $(0.01)$ & $(0.00)$ \\
\hline \multirow{2}{*}{ Nasdaq } & & & & \\
& $7 / 1988-2002$ & -0.08 & -0.21 & -0.16 \\
& $7 / 1988-1994$ & $(0.32)$ & $(0.01)$ & $(0.03)$ \\
& -0.06 & -0.26 & -0.19 \\
& $1995-2002$ & $(0.64)$ & $(0.03)$ & $(0.10)$ \\
& -0.21 & -0.44 & -0.47 \\
& $(0.04)$ & $(0.00)$ & $(0.00)$ \\
\hline
\end{tabular}

Panel B: Correlations with change in \% market short

\begin{tabular}{ccccc}
\hline \multirow{2}{*}{ NYSE-Amex } & $1976-2002$ & -0.30 & -0.16 & -0.11 \\
& & $(0.00)$ & $(0.00)$ & $(0.05)$ \\
& $7 / 1988-2002$ & -0.42 & -0.23 & -0.12 \\
& & $(0.00)$ & $(0.00)$ & $(0.13)$ \\
& $1995-2002$ & -0.37 & -0.17 & -0.14 \\
& & $(0.00)$ & $(0.09)$ & $(0.17)$ \\
\hline \multirow{2}{*}{ Nasdaq } & & & & \\
& $7 / 1988-2002$ & -0.18 & -0.09 & -0.00 \\
& & $(0.02)$ & $(0.24)$ & $(0.96)$ \\
& $7 / 1988-1994$ & -0.27 & -0.06 & 0.17 \\
& & $(0.02)$ & $(0.64)$ & $(0.14)$ \\
& $1995-2002$ & -0.14 & -0.11 & -0.06 \\
& & $(0.16)$ & $(0.30)$ & $(0.54)$ \\
\hline
\end{tabular}




\section{Table 3}

\section{Firms in the $99^{\text {th }}$ Percentile Portfolio in December 2002}

Short interest ratio is short interest in November 2002 divided by shares outstanding. Market cap is as of June 30, 2002. Book value of equity is for the end of the fiscal year ending during calendar 2002, or (for three companies that have not filed 2002 annual reports as of August 2003) the latest quarterly report during 2002. The 12-month prior return is for the 12 months ending in November 2002. The short interest ratio cutoff for NYSE-Amex firms is independent of the cutoff for Nasdaq firms.

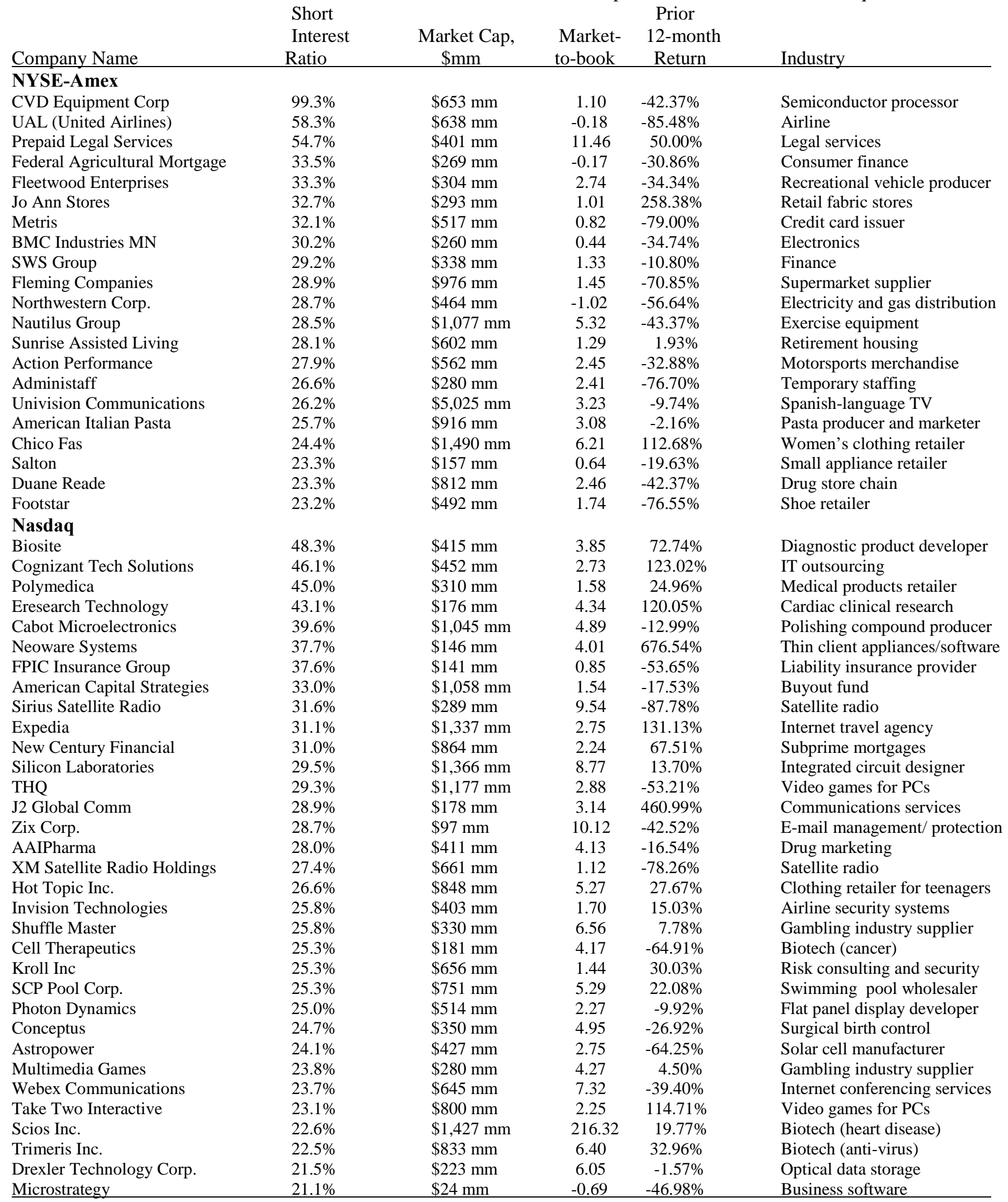




\section{Table 4}

\section{Descriptive Statistics}

Table 4 reports the distribution of the length of time that a firm spends in the untruncated high short interest portfolio once it enters. For example, for firms that first crossed the $2.5 \%$ short interest ratio threshold, $32.1 \%$ of them fell back below $2.5 \%$ in the following month. A firm that reenters the $2.5 \%$ portfolio after falling out is treated as a new observation.

Percentage of firms categorized by persistence and median months in portfolio

\begin{tabular}{cccccc} 
& \multicolumn{5}{c}{ Distribution of the length of time spent in a portfolio once entering } \\
\cline { 2 - 5 } Portfolio & 1 month & $2-3$ months & $4-12$ months & $\begin{array}{c}13 \text { or more } \\
\text { months }\end{array}$ & $\begin{array}{c}\text { median } \\
\text { months }\end{array}$ \\
\hline $2.5 \%$ & $32.1 \%$ & $22.1 \%$ & $26.7 \%$ & $19.1 \%$ & 3 \\
$5.0 \%$ & $30.9 \%$ & $22.9 \%$ & $28.6 \%$ & $17.6 \%$ & 3 \\
$10.0 \%$ & $32.9 \%$ & $23.4 \%$ & $29.5 \%$ & $14.2 \%$ & 3 \\
$95 \%$ ile & $34.1 \%$ & $23.7 \%$ & $26.7 \%$ & $15.5 \%$ & 3 \\
$99 \%$ ile & $35.6 \%$ & $26.8 \%$ & $26.5 \%$ & $11.5 \%$ & 2 \\
\hline
\end{tabular}




\section{Table 5}

\section{EW Raw Returns and Four-factor Model Intercepts for Firms with Short Interest Ratio $\geq 2.5 \%$ or in the $99^{\text {th }}$ Percentile, for 1,6 , and 12 Months after Portfolio Formation}

Columns 1-3 report monthly arithmetic average percentage raw returns for firms with high short interest in month 0 during periods of, respectively, 1 month, 6 months, and 12 months starting at the beginning of the following calendar month. Each portfolio from a calendar month during a sample period is weighted equally. Columns 4-6 report intercepts from four-factor regressions using monthly percentage returns, as described in Table 6, where a firm is included in the portfolio for calendar month t if it qualified for inclusion in the portfolio in at least one month during, respectively, month $t-1$, months $t-6$ to $t-1$, or months t-12 to t-1. For Nasdaq firms, we include only stocks listed on the National Market System (NMS). An intercept of 0.08 means 8 basis points per month.

Panel A: Short Interest Ratio $\geq \mathbf{2 . 5 \%}$

Monthly average raw return, $\%$ Monthly average 4-factor intercepts

$[1,1] \quad[1,6] \quad[1,12] \quad \frac{}{21,1]} \quad[1,6] \quad[1,12]$

(2)

(3)

(4)

(5)

(6)

\begin{tabular}{|c|c|c|c|c|c|c|}
\hline \multicolumn{7}{|l|}{ NYSE-Amex-Nasdaq } \\
\hline July 1988 - 2002 & 0.08 & 0.24 & 0.35 & -0.48 & -0.31 & -0.18 \\
\hline \multicolumn{7}{|l|}{ NYSE-Amex } \\
\hline 1976 - June 1988 & 1.68 & 1.86 & 1.84 & -0.11 & 0.13 & 0.15 \\
\hline July $1988-2002$ & 0.26 & 0.44 & 0.52 & -0.65 & -0.46 & -0.37 \\
\hline $1976-2002$ & 0.91 & 1.10 & 1.13 & -0.51 & -0.29 & -0.24 \\
\hline \multicolumn{7}{|l|}{ Nasdaq } \\
\hline July $1988-2002$ & 0.03 & 0.08 & 0.22 & -0.42 & -0.28 & -0.11 \\
\hline
\end{tabular}

\section{Panel B: Short Interest Ratio in the $99^{\text {th }}$ Percentile}

\begin{tabular}{|c|c|c|c|c|c|c|}
\hline \multicolumn{7}{|l|}{ NYSE-Amex-Nasdaq } \\
\hline July $1988-2002$ & -0.71 & -0.44 & -0.38 & -1.25 & -0.94 & -0.77 \\
\hline \multicolumn{7}{|l|}{ NYSE-Amex } \\
\hline 1976 - June 1988 & 2.12 & 2.17 & 2.12 & 0.29 & 0.41 & 0.37 \\
\hline July 1988 - 2002 & -0.82 & -0.50 & -0.42 & -1.46 & -1.35 & -1.29 \\
\hline $1976-2002$ & 0.54 & 0.74 & 0.75 & -0.72 & -0.64 & -0.62 \\
\hline \multicolumn{7}{|l|}{ Nasdaq } \\
\hline July $1988-2002$ & -0.73 & -0.43 & -0.31 & -1.27 & -0.71 & -0.51 \\
\hline
\end{tabular}




\section{Table 6}

\section{Four Factor Model Parameters for EW and VW Portfolios of NYSE-Amex-Nasdaq Stocks with High Short Interest, July 1988-December 2002}

In the time series regressions using monthly returns, the dependent variable is $r_{p t}-r_{f t}$, the excess return over the riskfree rate on a portfolio in time period $t, r_{m t}-r_{f t}$ is the realization of the market risk premium in period $t, \mathrm{SMB}_{\mathrm{t}}$ is the return on a portfolio of Small stocks Minus the return on a portfolio of Big stocks in period $t, H M L_{t}$ is the return on a portfolio of High book-to-market (value) Minus Low book-to-market (growth) stocks in period $t$, and $\mathrm{MOM}_{\mathrm{t}}$ is the return on a portfolio of prior winners minus the return on a portfolio of prior losers. The monthly factor return realizations are provided by Kenneth French. For July 1988-December 2002, 174 monthly returns are used in the regressions. The $2.5 \%$ portfolio in month $\mathrm{t}$ is the portfolio composed of all Amex, NYSE, and Nasdaq National Market System stocks with a short interest ratio of greater than 2.5\% (short interest/shares outstanding) in month t-1. The portfolio is updated monthly. The $5.0 \%, 10 \%, 95^{\text {th }}$ percentile, and $99^{\text {th }}$ percentile portfolios are defined analogously. T-statistics are shown in parentheses. An intercept of -0.48 means -48 basis points per month.

$$
r_{p t}-r_{f t}=a+b\left(r_{m t}-r_{f t}\right)+s S M B_{t}+h H M L_{t}+m M O M_{t}+e_{p t}
$$

Panel A: Untruncated EW NYSE-Amex-Nasdaq Firms July 1988 - December 2002

\begin{tabular}{ccccccc}
\hline Sample & Intercept & RMRF & SMB & HML & MOM & $\mathrm{R}^{2}$ adj \\
\hline $2.5 \%$ & -0.48 & 1.25 & 1.01 & -0.07 & -0.37 & 0.93 \\
& $(-2.79)$ & $(27.22)$ & $(21.04)$ & $(-1.12)$ & $(-10.76)$ & \\
$\geq 5.0 \%$ & -0.69 & 1.30 & 1.14 & -0.08 & -0.42 & 0.92 \\
& $(-3.53)$ & $(25.18)$ & $(21.00)$ & $(-1.13)$ & $(-10.82)$ & \\
$\geq 10.0 \%$ & -0.78 & 1.28 & 1.25 & -0.24 & -0.51 & 0.88 \\
& $(-2.87)$ & $(17.84)$ & $(16.52)$ & $(-2.50)$ & $(-9.37)$ & \\
$\geq 95^{\text {th }} \%$ ile & -0.54 & 1.30 & 1.16 & -0.13 & -0.43 & 0.92 \\
& $(-2.67)$ & $(24.07)$ & $(20.50)$ & $(-1.82)$ & $(-10.72)$ & \\
$\geq 99^{\text {th }} \%$ ile & -1.25 & 1.33 & 1.38 & -0.08 & -0.41 & 0.87 \\
& $(-4.42)$ & $(17.73)$ & $(17.52)$ & $(-0.84)$ & $(-7.33)$ & \\
\hline
\end{tabular}

Panel B: Truncated EW NYSE-Amex-Nasdaq Firms July 1988 - December 2002

\begin{tabular}{ccccccc}
\hline Sample & Intercept & RMRF & SMB & HML & MOM & $\mathrm{R}^{2}$ adj \\
\hline \multirow{2}{*}{$2.5-4.9 \%$} & -0.28 & 1.19 & 0.89 & -0.07 & -0.32 & 0.91 \\
& $(-1.58)$ & $(24.95)$ & $(17.77)$ & $(-1.14)$ & $(-8.92)$ & \\
$5.0-9.9 \%$ & -0.62 & 1.31 & 1.09 & -0.01 & -0.39 & 0.91 \\
& $(-3.00)$ & $(23.83)$ & $(18.82)$ & $(-0.10)$ & $-9.39)$ & \\
$95-98.9^{\text {th }} \%$ ile & -0.36 & 1.29 & 1.00 & -0.14 & -0.44 & 0.91 \\
& $(-1.74)$ & $(23.11)$ & $(18.86)$ & $(-1.91)$ & $(-10.48)$ & \\
\hline
\end{tabular}


Table 6 (continued)

Panel C: Untruncated VW NYSE-Amex-Nasdaq Firms, July 1988 - December 2002

\begin{tabular}{ccccccc}
\hline$\geq 2.5 \%$ & 0.16 & 1.23 & 0.38 & -0.29 & -0.26 & 0.92 \\
& $(1.02)$ & $(28.57)$ & $(8.51)$ & $(-5.06)$ & $(-7.89)$ & \\
$\geq 5.0 \%$ & -0.14 & 1.33 & 0.57 & -0.37 & -0.30 & 0.92 \\
& $(-0.76)$ & $(27.21)$ & $(11.08)$ & $(-5.81)$ & $(-8.28)$ & \\
$\geq 10.0 \%$ & -0.27 & 1.36 & 0.86 & -0.45 & -0.31 & 0.83 \\
& $(-0.86)$ & $(16.33)$ & $(9.89)$ & $(-4.14)$ & $(-4.97)$ & \\
$\geq 95^{\text {th }} \%$ ile & 0.24 & 1.27 & 0.56 & -0.46 & -0.34 & 0.92 \\
& $(1.24)$ & $(25.25)$ & $(10.65)$ & $(-7.00)$ & $(-8.98)$ & \\
$\geq 99^{\text {th }} \%$ ile & -0.38 & 1.42 & 1.18 & -0.30 & -0.17 & 0.81 \\
& $(-1.09)$ & $(15.26)$ & $(12.09)$ & $(-2.44)$ & $(-2.48)$ & \\
\hline
\end{tabular}

Panel D: Truncated VW NYSE-Amex-Nasdaq Firms, July 1988 - December 2002

\begin{tabular}{ccccccc}
\hline 2.5-4.9\% & 0.31 & 1.18 & 0.29 & -0.23 & -0.22 & 0.88 \\
& $(1.69)$ & $(23.77)$ & $(5.63)$ & $(-3.60)$ & $(-5.91)$ & \\
$5.0-9.9 \%$ & -0.11 & 1.33 & 0.50 & -0.31 & -0.31 & 0.90 \\
& $(-0.55)$ & $(24.75)$ & $(8.76)$ & $(-4.43)$ & $(-7.64)$ & \\
$95-98.9^{\text {th }} \%$ ile & 0.32 & 1.25 & 0.48 & -0.47 & -0.36 & 0.91 \\
& $(1.63)$ & $(23.89)$ & $(8.77)$ & $(-6.83)$ & $(-9.18)$ & \\
\hline
\end{tabular}




\section{Table 7: Characteristics of Highly Shorted Firms}

Panel A reports the size (market capitalization) for firms in the respective short interest portfolios, and for firms whose short interest ratio is lower than required for inclusion. For firms with a missing size value in year $t$, the year $\mathrm{t}-1$ size value is used. Size is calculated by taking the year end market price times the shares outstanding at year end. Panel B reports the median market-to-book ratio of equity for firms in the respective short interest portfolios, and for firms whose short interest ratio is lower than required for inclusion. For firms with a missing book value in year t, the year t-1 book value is used. Book values are from Compustat. Nasdaq firms include only National Market System (NMS) listings.

Panel A: Median Size, \$ millions

\begin{tabular}{|c|c|c|c|c|c|c|}
\hline \multirow[b]{2}{*}{ Portfolio } & \multicolumn{2}{|c|}{ All firms, 1976-2002 } & \multicolumn{2}{|c|}{ NYSE-Amex, 1976-2002 } & \multicolumn{2}{|c|}{ Nasdaq, July 1988-2002 } \\
\hline & Highly shorted & Others & Highly shorted & Others & Highly shorted & Others \\
\hline $2.5-4.9 \%$ & 392 & 74 & 708 & 174 & 237 & 43 \\
\hline $5.0-9.9 \%$ & 334 & 76 & 475 & 184 & 265 & 44 \\
\hline$\geq 10.0 \%$ & 303 & 78 & 350 & 188 & 280 & 45 \\
\hline $\begin{array}{c}95-98.9^{\text {th }} \\
\% \text { ile }\end{array}$ & 257 & 75 & 276 & 187 & 196 & 44 \\
\hline$\geq 99^{\text {th }} \%$ ile & 207 & 79 & 202 & 191 & 192 & 46 \\
\hline
\end{tabular}

Panel B: Median Market-to-book Ratios

\begin{tabular}{|c|c|c|c|c|c|c|}
\hline \multirow[b]{2}{*}{ Portfolio } & \multicolumn{2}{|c|}{ All firms, 1976-2002 } & \multicolumn{2}{|c|}{ NYSE-Amex, 1976-2002 } & \multicolumn{2}{|c|}{ Nasdaq, July 1988-2002 } \\
\hline & Highly shorted & Others & Highly shorted & Others & Highly shorted & Others \\
\hline $2.5-4.9 \%$ & 2.34 & 1.48 & 1.77 & 1.31 & 3.14 & 1.69 \\
\hline $5.0-9.9 \%$ & 2.45 & 1.49 & 1.83 & 1.32 & 3.26 & 1.71 \\
\hline$\geq 10.0 \%$ & 2.58 & 1.50 & 1.64 & 1.33 & 3.46 & 1.72 \\
\hline $\begin{array}{c}95-98.9^{\text {th }} \\
\% \text { ile }\end{array}$ & 2.02 & 1.50 & 1.53 & 1.33 & 2.96 & 1.70 \\
\hline$\geq 99^{\text {th }} \%$ ile & 2.21 & 1.51 & 1.60 & 1.33 & 3.19 & 1.73 \\
\hline
\end{tabular}




\section{Table 8}

\section{Four Factor Model Parameters for EW and VW Portfolios of NYSE-Amex Stocks and of Nasdaq Stocks with High Short Interest, July 1988-December 2002}

In the time series regressions using monthly percentage returns, the dependent variable is $r_{p t}-r_{f t}$, the excess return over the risk-free rate on a portfolio in time period $t, r_{m t}-r_{f t}$ is the realization of the market risk premium in period $t$, $\mathrm{SMB}_{\mathrm{t}}$ is the return on a portfolio of Small stocks Minus the return on a portfolio of Big stocks in period $t$, HML $\mathrm{t}_{\mathrm{t}}$ the return on a portfolio of High book-to-market (value) Minus Low book-to-market (growth) stocks in period t, and $\mathrm{MOM}_{\mathrm{t}}$ is the return on a portfolio of prior winners minus the return on a portfolio of prior losers. For July 1988December 2002, 174 observations are used in the regressions. The $2.5 \%$ portfolio is the portfolio composed of all Nasdaq stocks with a short interest ratio of greater than $2.5 \%$ (short interest/shares outstanding) in month $\mathrm{t}-1$. The portfolio is updated monthly. The $5.0 \%$ and $10.0 \%$ portfolios are defined analogously. The $95^{\text {th }}$ percentile portfolio is composed of all stocks that are in the top five percent of short interest ratios in month $t-1$. The $99^{\text {th }}$ percentile portfolio is defined analogously. An intercept of -0.41 means -41 basis points.

$$
r_{p t}-r_{f t}=a+b\left(r_{m t}-r_{f t}\right)+s S M B_{t}+h H M L_{t}+m_{M O M}+e_{p t}
$$

Panel A: EW NYSE-Amex Firms, July 1988 - December 2002

\begin{tabular}{|c|c|c|c|c|c|c|}
\hline Sample & Intercept & RMRF & SMB & HML & MOM & $\mathrm{R}^{2} \mathrm{adj}$ \\
\hline $2.5-4.9 \%$ & $\begin{array}{c}-0.41 \\
(-2.12)\end{array}$ & $\begin{array}{c}1.20 \\
(23.51)\end{array}$ & $\begin{array}{c}0.62 \\
(11.45)\end{array}$ & $\begin{array}{c}0.67 \\
(9.92)\end{array}$ & $\begin{array}{c}-0.23 \\
(-5.91)\end{array}$ & 0.83 \\
\hline $5.0-9.9 \%$ & $\begin{array}{c}-0.77 \\
(-3.47)\end{array}$ & $\begin{array}{c}1.31 \\
(22.14)\end{array}$ & $\begin{array}{c}0.88 \\
(14.18)\end{array}$ & $\begin{array}{c}0.67 \\
(8.63)\end{array}$ & $\begin{array}{c}-0.30 \\
(-6.63)\end{array}$ & 0.83 \\
\hline$\geq 10.0 \%$ & $\begin{array}{c}-1.27 \\
(-4.11)\end{array}$ & $\begin{array}{c}1.29 \\
(15.66)\end{array}$ & $\begin{array}{c}1.06 \\
(12.21)\end{array}$ & $\begin{array}{c}0.56 \\
(5.15)\end{array}$ & $\begin{array}{c}-0.44 \\
(-7.11)\end{array}$ & 0.76 \\
\hline $95-98.9^{\text {th }} \%$ ile & $\begin{array}{c}-0.86 \\
(-3.79)\end{array}$ & $\begin{array}{c}1.36 \\
(22.41)\end{array}$ & $\begin{array}{c}0.96 \\
(15.15)\end{array}$ & $\begin{array}{c}0.75 \\
(9.42)\end{array}$ & $\begin{array}{c}-0.39 \\
(-8.54)\end{array}$ & 0.84 \\
\hline$\geq 99^{\text {th }} \%$ ile & $\begin{array}{c}-1.46 \\
(-3.71)\end{array}$ & $\begin{array}{c}1.32 \\
(12.62)\end{array}$ & $\begin{array}{c}1.13 \\
(10.31)\end{array}$ & $\begin{array}{c}0.45 \\
(3.27)\end{array}$ & $\begin{array}{c}-0.47 \\
(-5.98)\end{array}$ & 0.69 \\
\hline \multicolumn{7}{|c|}{ Panel B: EW Nasdaq Firms, July 1988 - December 2002} \\
\hline $2.5-4.9 \%$ & $\begin{array}{c}-0.24 \\
(-0.95)\end{array}$ & $\begin{array}{c}1.18 \\
(17.71)\end{array}$ & $\begin{array}{c}1.07 \\
(15.44)\end{array}$ & $\begin{array}{c}-0.56 \\
(-6.49)\end{array}$ & $\begin{array}{c}-0.41 \\
(-8.32)\end{array}$ & 0.89 \\
\hline $5.0-9.9 \%$ & $\begin{array}{c}-0.63 \\
(-2.27)\end{array}$ & $\begin{array}{c}1.33 \\
(17.80)\end{array}$ & $\begin{array}{c}1.22 \\
(15.76)\end{array}$ & $\begin{array}{c}-0.35 \\
(-3.57)\end{array}$ & $\begin{array}{l}-0.44 \\
(-8.05\end{array}$ & 0.88 \\
\hline$\geq 10.0 \%$ & $\begin{array}{c}-0.48 \\
(-1.25)\end{array}$ & $\begin{array}{c}1.27 \\
(12.23)\end{array}$ & $\begin{array}{c}1.28 \\
(11.94)\end{array}$ & $\begin{array}{c}-0.67 \\
(-4.98)\end{array}$ & $\begin{array}{c}-0.55 \\
(-7.24)\end{array}$ & 0.82 \\
\hline $95-98.9^{\text {th }} \%$ ile & $\begin{array}{c}-0.14 \\
(-0.55)\end{array}$ & $\begin{array}{c}1.26 \\
(18.79)\end{array}$ & $\begin{array}{c}1.17 \\
(16.78)\end{array}$ & $\begin{array}{c}-0.60 \\
(-6.91)\end{array}$ & $\begin{array}{c}-0.45 \\
(-9.03)\end{array}$ & 0.91 \\
\hline$\geq 99^{\text {th }} \%$ ile & $\begin{array}{c}-1.27 \\
(-3.49)\end{array}$ & $\begin{array}{c}1.30 \\
(13.38)\end{array}$ & $\begin{array}{c}1.35 \\
(13.38)\end{array}$ & $\begin{array}{c}-0.37 \\
(-2.90)\end{array}$ & $\begin{array}{c}-0.43 \\
(-6.04)\end{array}$ & 0.82 \\
\hline
\end{tabular}




\section{Table 8 (continued)}

Panel C: VW NYSE-Amex Firms, July 1988 - December 2002

\begin{tabular}{|c|c|c|c|c|c|c|}
\hline Sample & Intercept & RMRF & SMB & HML & MOM & $\mathrm{R}^{2} \mathrm{adj}$ \\
\hline $2.5-4.9 \%$ & $\begin{array}{c}0.34 \\
(2.06)\end{array}$ & $\begin{array}{c}1.13 \\
(26.09)\end{array}$ & $\begin{array}{c}0.21 \\
(4.49)\end{array}$ & $\begin{array}{c}0.24 \\
(4.17)\end{array}$ & $\begin{array}{c}-0.18 \\
(-5.54)\end{array}$ & 0.86 \\
\hline $5.0-9.9 \%$ & $\begin{array}{c}-0.32 \\
(-1.49)\end{array}$ & $\begin{array}{c}1.27 \\
(22.34)\end{array}$ & $\begin{array}{c}0.29 \\
(4.93)\end{array}$ & $\begin{array}{c}0.32 \\
(4.24)\end{array}$ & $\begin{array}{c}-0.30 \\
(-7.07)\end{array}$ & 0.82 \\
\hline$\geq 10.0 \%$ & $\begin{array}{c}-0.66 \\
(-1.61)\end{array}$ & $\begin{array}{c}1.39 \\
(12.83)\end{array}$ & $\begin{array}{c}0.66 \\
(5.79)\end{array}$ & $\begin{array}{c}0.46 \\
(3.24)\end{array}$ & $\begin{array}{c}-0.28 \\
(-3.42)\end{array}$ & 0.61 \\
\hline $95-98.9^{\text {th }} \%$ ile & $\begin{array}{c}-0.24 \\
(-0.95)\end{array}$ & $\begin{array}{c}1.27 \\
(19.12)\end{array}$ & $\begin{array}{c}0.38 \\
(5.43)\end{array}$ & $\begin{array}{c}0.31 \\
(3.51)\end{array}$ & $\begin{array}{c}-0.39 \\
(-7.71)\end{array}$ & 0.79 \\
\hline$\geq 99^{\text {th }} \%$ ile & $\begin{array}{c}-0.95 \\
(-1.85)\end{array}$ & $\begin{array}{c}1.50 \\
(10.94)\end{array}$ & $\begin{array}{c}0.76 \\
(5.25)\end{array}$ & $\begin{array}{c}0.34 \\
(1.90)\end{array}$ & $\begin{array}{c}-0.28 \\
(-2.68)\end{array}$ & 0.56 \\
\hline
\end{tabular}

Panel D: VW Nasdaq Firms, July 1988 - December 2002

\begin{tabular}{|c|c|c|c|c|c|c|}
\hline $2.5-4.9 \%$ & $\begin{array}{c}0.17 \\
(0.54)\end{array}$ & $\begin{array}{c}1.26 \\
(14.84)\end{array}$ & $\begin{array}{c}0.59 \\
(6.75)\end{array}$ & $\begin{array}{c}-0.90 \\
(-8.15)\end{array}$ & $\begin{array}{c}-0.26 \\
(-4.16)\end{array}$ & 0.84 \\
\hline $5.0 \%-9.9 \%$ & $\begin{array}{c}0.11 \\
(0.33)\end{array}$ & $\begin{array}{c}1.55 \\
(17.45)\end{array}$ & $\begin{array}{c}0.78 \\
(8.47)\end{array}$ & $\begin{array}{c}-0.80 \\
(-6.91)\end{array}$ & $\begin{array}{c}-0.28 \\
(-4.27)\end{array}$ & 0.86 \\
\hline$\geq 10.0 \%$ & $\begin{array}{c}0.08 \\
(0.19)\end{array}$ & $\begin{array}{c}1.30 \\
11.33\end{array}$ & $\begin{array}{c}0.97 \\
(8.22)\end{array}$ & $\begin{array}{c}-1.05 \\
(-7.09)\end{array}$ & $\begin{array}{c}-0.37 \\
(-4.42)\end{array}$ & 0.80 \\
\hline $95-98.9^{\text {th }} \%$ ile & $\begin{array}{c}0.95 \\
(3.62)\end{array}$ & $\begin{array}{c}1.38 \\
(19.61)\end{array}$ & $\begin{array}{c}0.64 \\
(8.86)\end{array}$ & $\begin{array}{c}-1.04 \\
(-11.44)\end{array}$ & $\begin{array}{c}-0.33 \\
(-6.31)\end{array}$ & 0.91 \\
\hline$\geq 99^{\text {th }} \%$ ile & $\begin{array}{c}-0.73 \\
(-1.66)\end{array}$ & $\begin{array}{c}1.44 \\
(12.15)\end{array}$ & $\begin{array}{c}1.17 \\
(9.57)\end{array}$ & $\begin{array}{c}-0.79 \\
(-5.13)\end{array}$ & $\begin{array}{c}-0.05 \\
(-0.62)\end{array}$ & 0.79 \\
\hline
\end{tabular}




\section{Table 9}

\section{Four Factor Model Parameters for EW and VW Portfolios of Firms with High Short Interest, by Subperiod}

Intercepts and their t-statistics from monthly time series regressions of $r_{p t}-r_{f t}$, the percentage excess return over the risk-free rate on a portfolio in time period $t$, regressed on $r_{m t}-r_{f t}$ is the realization of the market risk premium in period $\mathrm{t}, \mathrm{SMB}_{\mathrm{t}}$ is the return on a portfolio of Small stocks Minus the return on a portfolio of Big stocks in period $t, \mathrm{HML}_{\mathrm{t}}$ is the return on a portfolio of High book-to-market (value) Minus Low book-to-market (growth) stocks in period $t$, and $\mathrm{MOM}_{\mathrm{t}}$ is the return on a portfolio of prior winners minus the return on a portfolio of prior losers, are reported. For July 1988-December 1994, 78 monthly returns are used in the regressions. For January 1995 to December 2002, 96 monthly returns are used. The 2.5\% portfolio in month $\mathrm{t}$ is the portfolio composed of all Nasdaq stocks in with a short interest ratio of greater than $2.5 \%$ (short interest/shares outstanding) in month $\mathrm{t}-1$. The portfolio is updated monthly. The $99^{\text {th }}$ percentile portfolio in month $t$ is composed of all stocks that are in the top one percent of short interest ratios in month $\mathrm{t}-1$.

$$
r_{p t}-r_{f t}=a+b\left(r_{m t}-r_{f t}\right)+s S M B_{t}+h H M L_{t}+m M O M_{t}+e_{p t}
$$

Four-factor model intercepts

\begin{tabular}{|c|c|c|c|c|}
\hline \multirow[b]{2}{*}{ Sample } & \multicolumn{2}{|c|}{ Equally Weighted } & \multicolumn{2}{|c|}{ Value Weighted } \\
\hline & $2.5-4.9 \%$ & $99^{\text {th }} \%$ ile & $2.5-4.9 \%$ & $99^{\text {th }} \%$ ile \\
\hline \multicolumn{5}{|c|}{ Panel A: All Markets (NYSE-Amex only prior to July 1988) } \\
\hline \multirow[t]{2}{*}{ July 1988-1994 } & $-0.62^{* * * *}$ & $-1.36^{* * * *}$ & $0.42^{*}$ & $-1.00^{* * * *}$ \\
\hline & $(-2.46)$ & $(-3.54)$ & $(1.90)$ & $(-2.45)$ \\
\hline \multirow[t]{2}{*}{ 1995-2002 } & -0.05 & $-1.18^{* * *}$ & 0.25 & 0.13 \\
\hline & $(-0.21)$ & $(-2.92)$ & $(0.91)$ & $(0.24)$ \\
\hline \multirow[t]{2}{*}{ July 1988-2002 } & -0.28 & $-1.25^{* * *}$ & $0.31^{*}$ & -0.38 \\
\hline & $(-1.58)$ & $(-4.42)$ & (1.69) & $(-1.09)$ \\
\hline \multirow{2}{*}{$1976-2002$} & $-0.28^{* *}$ & $-0.53^{* * *}$ & $0.27^{*}$ & -0.05 \\
\hline & $(-2.08)$ & $(-2.44)$ & $(1.76)$ & $(-0.17)$ \\
\hline \multicolumn{5}{|c|}{ Panel B: NYSE-Amex } \\
\hline \multirow[t]{2}{*}{ 1976-June 1988} & -0.28 & 0.29 & 0.17 & 0.44 \\
\hline & $(-1.47)$ & $(0.94)$ & $(0.67)$ & $(0.94)$ \\
\hline \multirow[t]{2}{*}{ July 1988-1994 } & -0.45 & $-1.62^{* * * *}$ & $0.55^{* * * *}$ & $-1.45^{* *}$ \\
\hline & $(-1.53)$ & $(-2.75)$ & $(2.41)$ & $(-2.32)$ \\
\hline \multirow[t]{2}{*}{$1995-2002$} & $-0.34^{*}$ & $-1.36^{* * * *}$ & 0.23 & -0.64 \\
\hline & $(-1.72)$ & $(-2.67)$ & $(0.99)$ & $(-0.90)$ \\
\hline \multirow[t]{2}{*}{ July 1988-2002 } & $-0.41^{* *}$ & $-1.46^{* * * *}$ & $0.34^{* * *}$ & $-0.95^{*}$ \\
\hline & $(-2.12)$ & $(-3.71)$ & $(2.06)$ & $(-1.85)$ \\
\hline \multirow[t]{2}{*}{$1976-2002$} & $-0.45^{* * *}$ & $-0.72^{* * *}$ & 0.21 & -0.42 \\
\hline & $(-2.88)$ & $(-2.68)$ & $(1.35)$ & $(-1.18)$ \\
\hline \multicolumn{5}{|c|}{ Panel C: Nasdaq } \\
\hline \multirow[t]{2}{*}{ July 1988-1994 } & $-0.89^{* * * *}$ & $-1.36^{\text {**** }}$ & -0.26 & $-1.59^{* * * *}$ \\
\hline & $(-2.56)$ & $(-3.03)$ & $(-0.61)$ & $(-3.20)$ \\
\hline \multirow[t]{2}{*}{$1995-2002$} & 0.20 & $-1.24^{* * *}$ & 0.51 & -0.06 \\
\hline & $(0.63)$ & $(-2.28)$ & $(1.16)$ & $(-0.09)$ \\
\hline \multirow[t]{2}{*}{ July 1988-2002 } & -0.24 & $-1.27^{* * *}$ & 0.17 & $-0.73^{*}$ \\
\hline & $(-0.95)$ & $(-3.49)$ & $(0.54)$ & $(-1.66)$ \\
\hline
\end{tabular}




\section{Table 10}

\section{Four Factor Model Parameters for EW Portfolios of Firms with High Short Interest, by Arbitrage Category, July 1988-December 2002}

Arbitrage shorts are firms with high short interest that have a convertible bond outstanding. Valuation shorts are all other firms with high short interest. Intercepts and their t-statistics from time series regressions using monthly percentage returns of $r_{p t}-r_{f t}$, the excess return over the risk-free rate on a portfolio in time period $t$, regressed on $r_{m t}-r_{f t}$ is the realization of the market risk premium in period $t$, $\mathrm{SMB}_{\mathrm{t}}$ is the return on a portfolio of Small stocks Minus the return on a portfolio of Big stocks in period $\mathrm{t}$, $\mathrm{HML}_{\mathrm{t}}$ is the return on a portfolio of High book-to-market (value) Minus Low book-to-market (growth) stocks in period $t$, and $\mathrm{MOM}_{\mathrm{t}}$ is the return on a portfolio of prior winners minus the return on a portfolio of prior losers, are reported. For July 1988-December 2002, 174 monthly returns are used. The 2.5\% portfolio in month $t$ is the portfolio composed of all Nasdaq stocks in with a short interest ratio of greater than $2.5 \%$ (short interest/shares outstanding) in month $\mathrm{t}-1$. The portfolio is updated monthly. The $99^{\text {th }}$ percentile portfolio in month $t$ is composed of all stocks that are in the top one percent of short interest ratios in month $\mathrm{t}-1$. Panel A reports the average percentage of firms that are in convertible arbitrage category.

$$
r_{p t}-r_{f t}=a+b\left(r_{m t}-r_{f t}\right)+s S M B_{t}+h H M L_{t}+m M O M_{t}+e_{p t}
$$

Panel A: Percentage of Firms with Convertibles Debt in Portfolios, July 1988-December 2002

All Firms $2.5-4.9 \% \quad 99^{\text {th }} \%$ ile

\begin{tabular}{ll}
$9.6 \%$ & $17.6 \%$ \\
\hline
\end{tabular}

Panel B: EW NYSE-Amex-Nasdaq firms, July 1988-December 2002

\begin{tabular}{|c|c|c|c|}
\hline \multicolumn{2}{|c|}{$2.5-4.9 \%$} & \multicolumn{2}{|c|}{$99^{\text {th }}$ Percentile } \\
\hline $\begin{array}{c}\text { Arbitrage } \\
\text { Short }\end{array}$ & $\begin{array}{c}\text { Valuation } \\
\text { Short } \\
\end{array}$ & $\begin{array}{c}\text { Arbitrage } \\
\text { Short }\end{array}$ & $\begin{array}{c}\text { Valuation } \\
\text { Short } \\
\end{array}$ \\
\hline $\begin{array}{c}-0.22 \\
(-1.09)\end{array}$ & $\begin{array}{c}-0.34 \\
(-1.57)\end{array}$ & $\begin{array}{c}-0.62 \\
(-1.76)\end{array}$ & $\begin{array}{c}-1.38 \\
(-4.05)\end{array}$ \\
\hline \multicolumn{4}{|c|}{ Panel C: EW NYSE-Amex firms, July 1988-December 2002} \\
\hline $\begin{array}{c}-0.40 \\
(-1.77)\end{array}$ & $\begin{array}{c}-0.41 \\
(-1.77)\end{array}$ & $\begin{array}{l}-0.24 \\
(-0.40)\end{array}$ & $\begin{array}{c}-1.87 \\
(-3.82)\end{array}$ \\
\hline \multicolumn{4}{|c|}{ Panel D: EW Nasdaq firms, July 1988-December 2002} \\
\hline $\begin{array}{c}0.08 \\
(0.22)\end{array}$ & $\begin{array}{c}-0.32 \\
(-1.14)\end{array}$ & $\begin{array}{c}-1.06 \\
(-1.89)\end{array}$ & $\begin{array}{c}-1.26 \\
(-3.01)\end{array}$ \\
\hline
\end{tabular}


NYSE-Amex Monthly Distribution of Short Interest 1976-2002

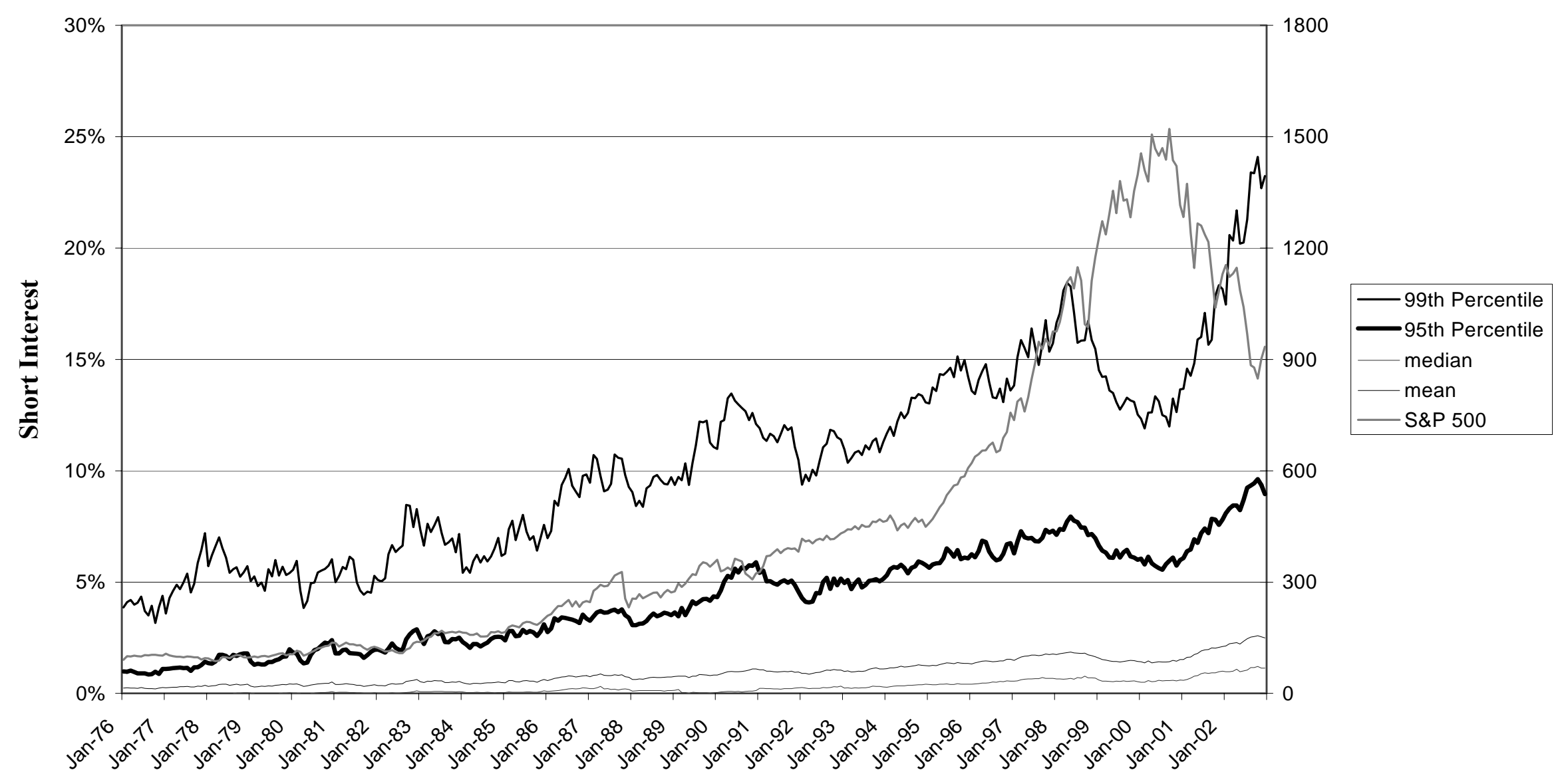

Figure 1 - The mean, median, 95th, and 99th percentiles of short interest ratios (scale on left axis) for NYSE and Amex stocks, and the level of the S\&P 500 (right axis), for January 1976 to December 2002. Short interest ratios are defined as short interest divided by shares outstanding. If no short interest is reported for a stock in a given month, the ratio is assumed to be zero. 


\section{Nasdaq Monthly Distribution of Short Interest 6/1988-2002}

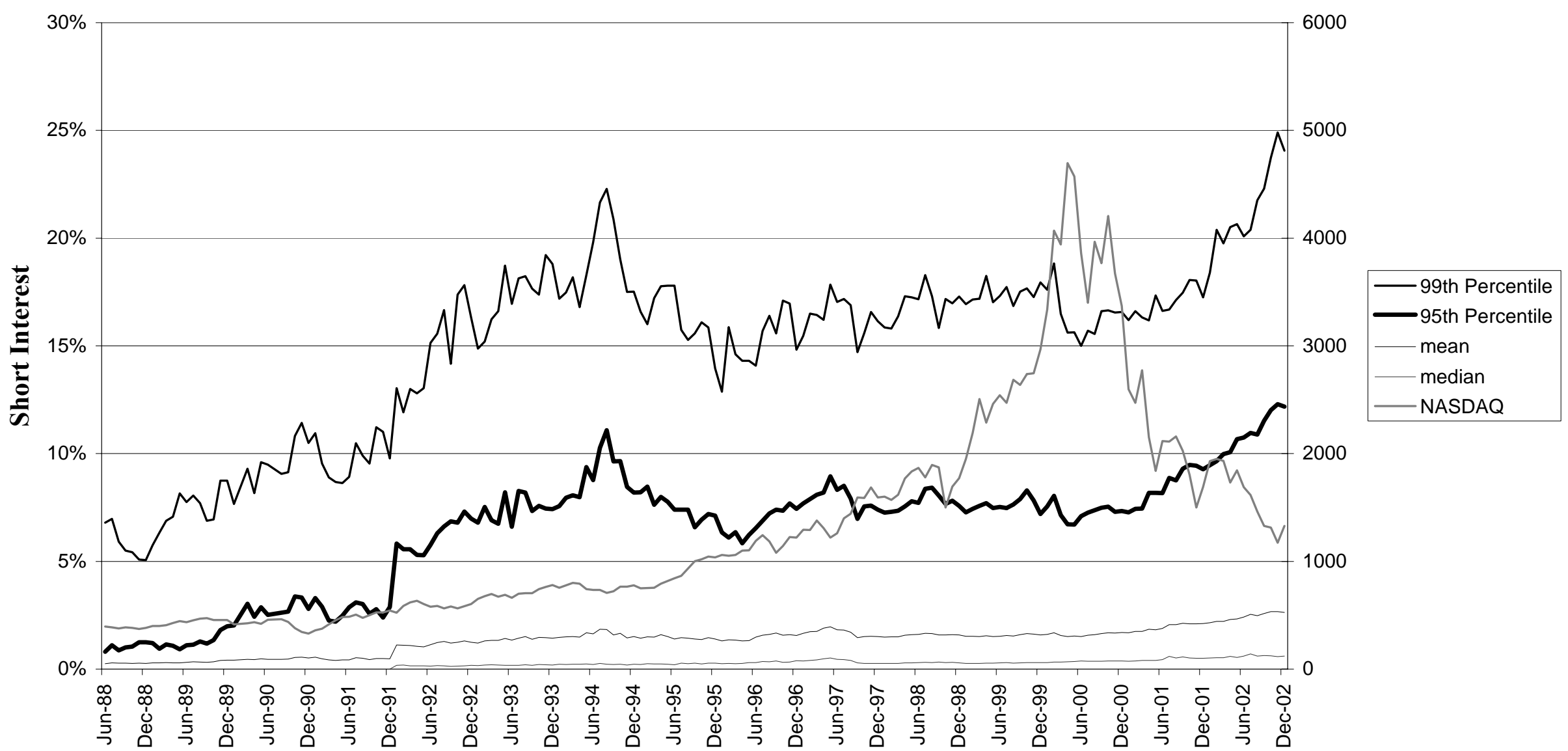

Figure 2-- The mean, median, 95th, and 99th percentiles of short interest ratios (left axis) of Nasdaq stocks, and the level of the Nasdaq Composite (right axis), from June 1988 to December 2002. The jump in short interest ratios in January 1992 is due to an increase in the number of firms for which Nasdaq reported positive short interest. 


\section{Short Interest in 99th Percentile (48-month rolling, NYSE-Amex Firms)}

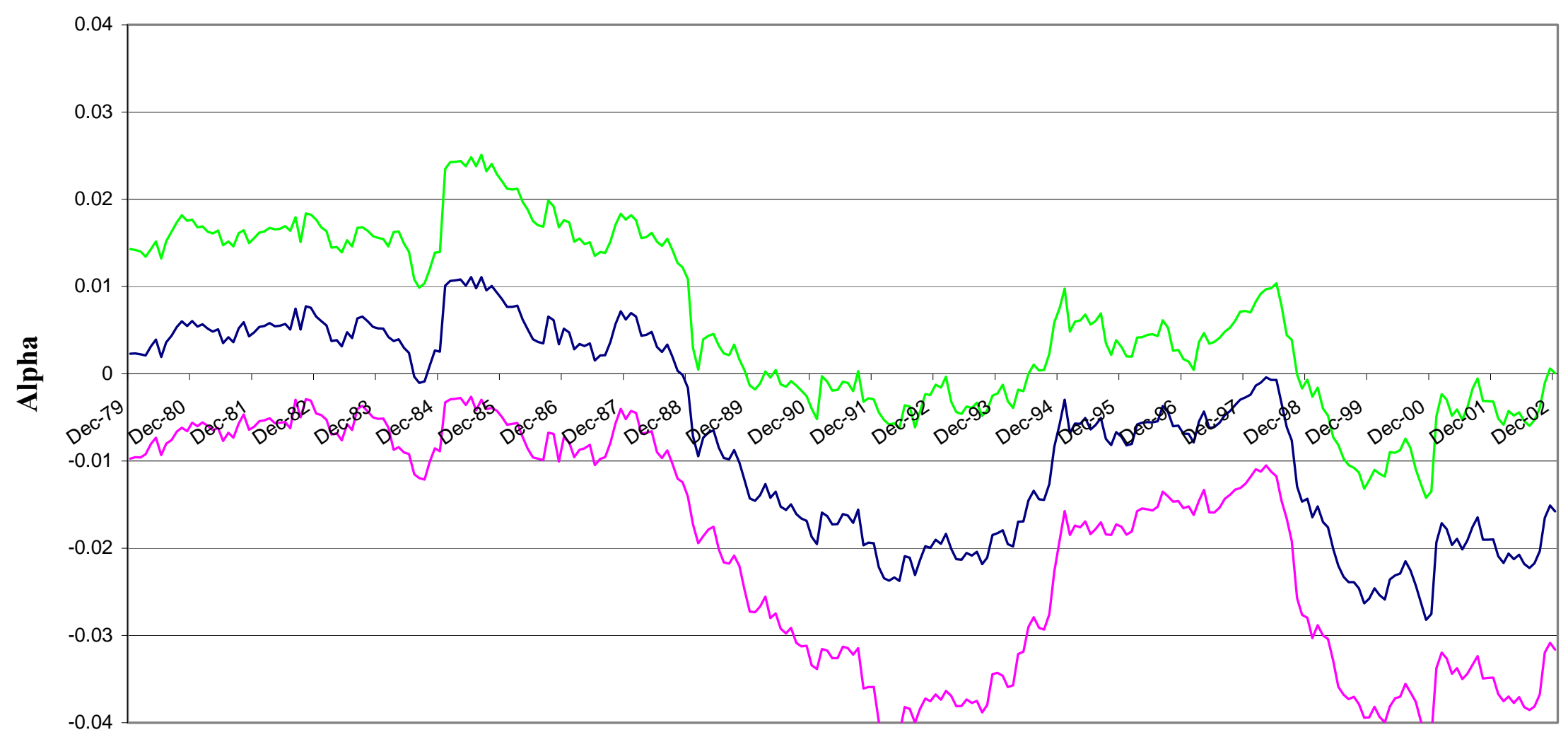

Date

Figure 3-Intercepts (and 5\% and 95\% confidence bands) from rolling 48-month four-factor regression with the market excess return, book-to-market, size, and momentum as the four factors. For month $\mathrm{t}$, the regression is estimated over the 48 months from month $\mathrm{t}-48$ to $t$. The vertical axis measures the intercept in units of monthly returns, with an alpha of -0.01 corresponding to -1.0 percent per month. 


\section{Short Interest in 99th Percentile (48-month rolling, Nasdaq Firms)}

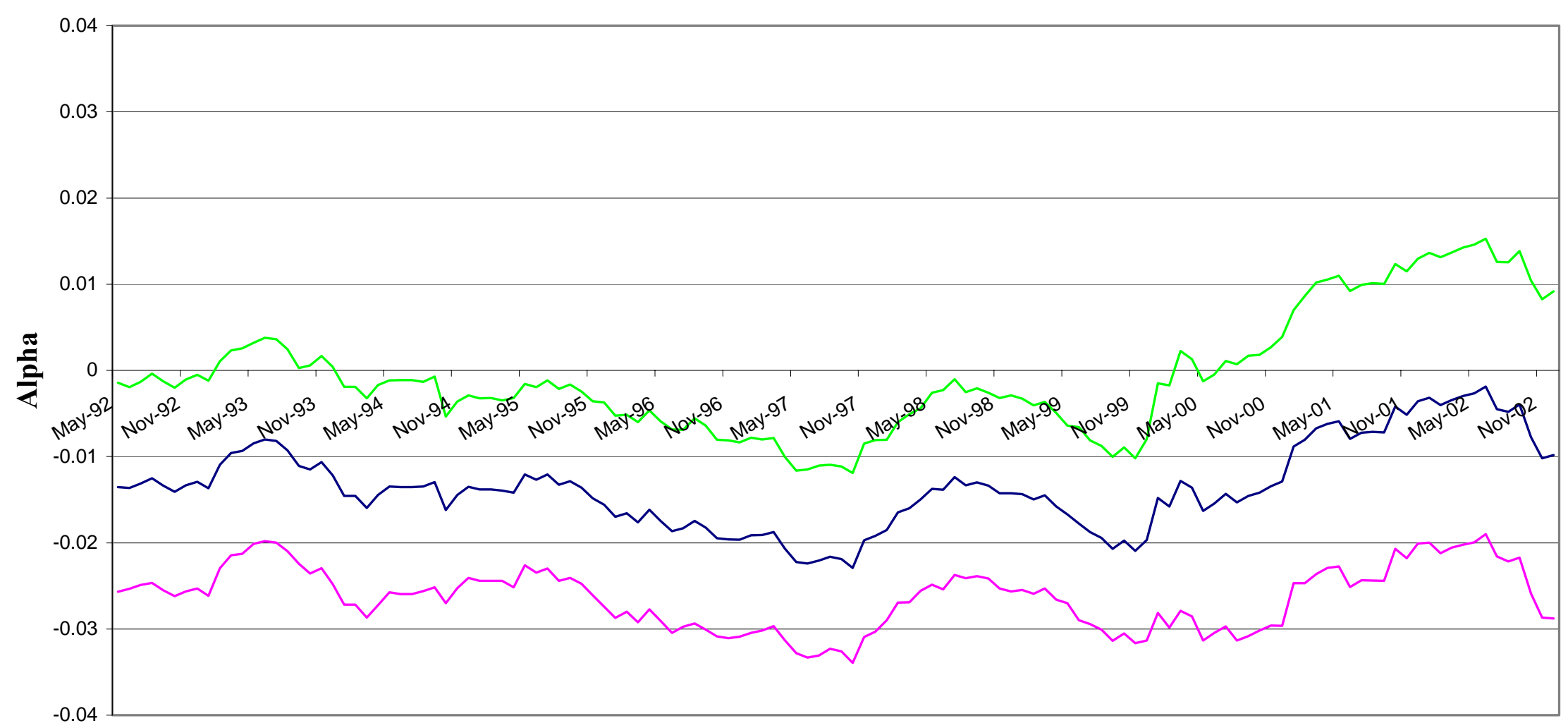

Date

Figure 4-Intercepts (and 5\% and 95\% confidence bands) from rolling 48-month four-factor regression with the market excess return, book-to-market, size, and momentum as the four factors. For month t, the regression is estimated over the 48 months from month t- 48 to $t$. The vertical axis measures the intercept in units of monthly returns, with an alpha of -0.01 corresponding to -1.0 percent per month. 